\title{
Öğretmenlerin Mesleki Tükenmişlik Düzeyleri ile Örgütsel Sinizm Tutumlarının İncelenmesi
}

\section{Neşe DUMAN*, Ramazan SAK ${ }^{* *}$ ve İkbal Tuba ŞAHİN SAK ${ }^{* * *}$}

Öz: Bu araştırmanın amacı, farklı branşlardan öğretmenlerin mesleki tükenmişlik düzeyleri ile örgütsel sinizm tutumlarının incelenmesidir. Tarama modelindeki bu araştırmanın örneklemini seçkisiz örnekleme yöntemiyle belirlenen farklı branşlardan 313 öğretmen oluşturmuştur. Maslach Tükenmişlik Envanteri-Eğitimci Formu, Örgütsel Sinizm Ölçeği ve Kişisel Bilgi Formu kullanılarak toplanan verilerin analizinde bağımsız örneklemler için t testi, Tek Faktörlü ANOVA ve Pearson Korelasyon Analizi gibi parametrik testler kullanılmıştır. Analizler sonucunda, öğretmenlerin mesleki tükenmişlik düzeyleri cinsiyetlerine, yaşlarına, kıdemlerine, öğrenim düzeylerine, sınıf mevcuduna, son bir yılda meslekleriyle ilgili bir eğitime/etkinliğe katılma durumlarına göre anlamlı bir farklılık göstermemiş; ancak, branşlarına, okuldaki çalışma durumlarına (kadrolu-ücretli), eğitim kademelerine ve çalıştıkları sektöre (özel-devlet) göre öğretmenlerin mesleki tükenmişlik düzeylerinde anlamlı farklılıklar bulunmuştur. Öğretmenlerin örgütsel sinizm tutumları ise, öğrenim düzeylerine göre anlamlı bir farklılık göstermezken, branşlarına, cinsiyetlerine, yaşlarına, kıdemlerine, çalışma durumlarına (kadrolu-ücretli), çalıştıkları kademeye, sektöre (özel-devlet) ve bir eğitime/etkinliğe katılma durumlarına göre anlamlı bir şekilde farklılaşmıştır. Ayrıca, öğretmenlerin mesleki tükenmişlik alt boyutları ile örgütsel sinizm tutumları arasında anlamlı bir ilişki bulunmuştur.

Anahtar Sözcükler: Öğretmenler, mesleki tükenmişlik, örgütsel sinizm.

${ }^{*}$ Dr. Öğr. Üyesi, Çankırı Karatekin Üniversitesi, Edebiyat Fakültesi, Orcid ID: 0000-0002-5398-8388, Email: neseduman@karatekin.edu.tr

**Doç. Dr., Van Yüzüncü Yıl Üniversitesi, Eğitim Fakültesi, Orcid ID: 0000-0002-7504-9429, Email: ramazansak06@gmail.com

***Doç. Dr., Van Yüzüncü Y1l Üniversitesi, Eğitim Fakültesi, Orcid ID: 0000-0002-9054-6212, Email: ikbalsahin@gmail.com

****Bu araştırma için Van Yüzüncü Yıl Üniversitesi Sosyal ve Beşeri Bilimler Yayın Etik Kurulu Başkanlığından (01/04/2020-25467) etik izin alınmıştır.

Gönderim:23.03.2020 Kabul:18.07.2020 Yayın:30.09.2020




\section{Examination of Teachers' Job Burnout Level and Organizational Cynicism Attitudes}

Abstract: The aim of this study is to examine job burnout levels and organizational cynicism attitudes of teachers from different departments. This survey consisted of 313 teachers selected randomly. The data was collected through Maslach Burnout Inventory-Educators Survey, Organizational Cynicism Scala and Personal Information Form and analyzed through parametric tests; The Independent Samples t-Test, One-way ANOVA and Pearson Correlation Coefficient. Analysis showed that there were no statistically significant differences in job burnout levels of teachers based on their genders, ages, teaching experiences, educational levels, class size and if they attended a training program or activities related to their job last year but a statistically significant difference was found based on their department, how they worked (hourly paid or salaried), the age group they taught and the sector they worked (public or private). There was no statistically significant difference in organizational cynicism attitudes of teachers based on their educational levels but a statistically significant difference was found based on their department, genders, ages, teaching experiences, how they worked (hourly paid or salaried), the age group they taught, the sector they worked (public or private) and if they attended a training program or activities related to their job last year. Also, there was a statistically significant relationship between teachers' job burnout levels and organizational cynicism attitudes.

Keywords: Teachers, job burnout, organizational cynicism.

\section{Giriş}

Kişinin kendini gerçekleştirmesi konusunda bireyi destekleme, kendine ve topluma fayda sağlayacak davranışlarda bulunması konusunda bireye rehber olma ve problemlere farklı çözüm yolları sunması için bireyin farklı becerilerini geliştirmesini sağlama, eğitimin amaçlarındandır (Ercan, 2003). Öğretmen eğitim sürecinin en önemli aktörlerindendir (Makovec, 2018) ve bu süreçte oynamış olduğu rol, sergilemiş olduğu davranışlar hem kendinin hem de öğrenciler, veliler, yöneticiler, meslektaşlar ve toplumun diğer üyeleri gibi çevresindeki diğer kişilerin beklentilerinden etkilenmektedir (Adams, 1970). Bu beklentiler öğretmenlik gibi sorumluluk isteyen bir mesleği daha da stresli hale getirmekte, bu strese bağlı olarak da öğretmenin tükenmişlik düzeyini yükseltmektedir (Mahmood ve Sak, 2019). Ayrıca öğretmenlik, hem fedakârlık isteyen ve kişiyi duygusal anlamda yıpratan hem de 
sürekli insanlarla etkileşim halinde olmayı ve etkili iletişim becerilerini kullanmayı gerektiren bir meslektir. Bu nedenle de tükenmişliğin en çok görüldüğü mesleklerden biri olarak ifade edilmektedir (Baltaş ve Baltaş, 1993).

Freudenberg (1989) tükenmişlik kavramını ilk kez 1973’te ortaya koyduğunu ifade etmiş ve "insanların aşırı çalışma sonucu artık işin gereklerini yerine getiremez bir duruma gelişlerini ifade eden duygusal tükenme durumu” şeklinde bir tanım yapmıştır (Freudenberg, 1974; akt. Ergin, 1996, s. 49). Maslach, Schaufeli ve Leiter (2001), tükenmişliğgin zor anlaşılır bir kavram olduğunu ve standart bir tanımının olmadığını belirtmişler, bununla birlikte mesleki tükenmişliği, tükenme, sinizm ve yetersizlik şeklinde üç boyuttan oluşan, işteki kronik duygusal ve kişilerarası stres faktörlerine gösterilen uzun süreli tepki şeklinde tanımlamışlardır. Cherniss'e (1980) göre ise tükenmişlik, kişinin mesleki doyuma ulaşamaması ve gereğinden fazla strese maruz kalması sonucunda mesleğinden soğumasıdır.

Mesleki tükenmişlik kişi açısından ciddi sorunları beraberinde getirmektedir. Işıkhan (2016) bu sonuçları, kişisel, çalışma hayatı ile ilgili ve aile hayatı ile ilgili sonuçlar başlıkları altında toplamıştır. Kişisel sonuçlardan bazıları, kişinin fiziksel yorgunluk hissetmesi ve güne başlamakta zorlanması, başarı duygusunun azalması ve benlik saygısına ilişkin olumsuz duygular geliştirmesi şeklinde sıralanabilir. Kişinin mesleki başarısının düşmesi, işe devamsızlık sorununun ortaya çıkması ve işini değiştirme isteği de çalışma hayatına ilişkin başlıca sonuçlardandır. Mesleki tükenmişlikle yakından ilişkili olarak ortaya çıkan duygusal tükenme, kişinin aile hayatına da yansımakta, aile içi çatışmalar ve aile üyelerinin birbirinden uzaklaşmalarına sebep olmaktadır (Işıkhan, 2016).

Son dönemde çeşitli çalışmalarda, kişinin negatif duygularının meslektaşlarına ve bireyin kendisine yönelik olduğu tükenmişlikle, bu duyguların içinde bulunduğu örgüte ya da üst düzey yöneticilere yönelik olduğu örgütsel sinizm (Alan ve Fidanboy, 2013) ilişsisine vurgu yapılmaktadır. Örneğin, Ercan ve Kazançoğlu (2019) sinizm kavramını açıklarken tükenmişliğe de vurgu yapmış ve sinizmi, kötümser kişilik, olumsuz hayat felsefesi, tükenmişlik ve hayal kırıklığı gibi olumsuz duyguları besleme ve güven sorunları gibi kavramlar üzerinden açıklamışlardır. Örgütsel sinizm ise, Johnson ve O'Leary-Kelly (2003) tarafından farklı kaynaklara atıfta bulunularak (örneğin; Andersson, 1996; Bateman, Sakano, ve Fujita, 1992; Dean, Brandes ve Dharwadkar, 1998), kişinin çalıştığı örgütte, dürüstlük, adalet ve doğruluk gibi temel beklentilerin ihlal edilmesine bağlı olarak örgütün dürüstlükten yoksun olduğuna dair algı sonucunda ortaya çıkan tutum şeklinde tanımlanmış ve bu tutumun yalnızca bir konuya yönelik olmadığı, zaman zaman birden fazla konuya yönelik olabileceği 
ve hatta bir konudan diğerine genellenebildiği ifade edilmiştir. Maslach vd. (2001) tarafından yapılan mesleki tükenmişlik tanımında da sinizm, tükenmişliğin bir boyutu olarak vurgulanmıştır. Dağyar ve Kasalak (2018) tarafından yapılmış olan bir meta analiz çalışması, özellikle eğitimciler açısından yüksek örgütsel sinizm düzeyinin, kişilerin mesleklerine yabancılaşmalarına ve düşünce ve görüşlerini ortaya koymaktan kaçınarak sessizliğe bürünmelerine neden olduğunu, ayrıca zayıf veya orta düzeyde de olsa kişilerin çalıştıkları kuruma katkı sağlama isteklerini ve iş-yaşam doyumlarını olumsuz etkilediğini göstermiştir. Ayrıca örgütsel sinizm, örgütsel vatandaşlık davranışı, iş tatmini, örgütsel bağlılık, motivasyon ve çalışanların değişim yaratma istekliliğini de olumsuz yönde etkilemektedir (Aydemir ve Karademir, 2017).

Alanyazında, öğretmenlerin mesleki tükenmişlikleri ile ilgili çeşitli çalışmalar bulunmaktadır. Örneğin; öğretmenlerin mesleki tükenmişlik düzeyleri çeşitli değişkenler açısından incelenmiş (Bağcı ve Karagül, 2013; Başol ve Altay, 2009; Durak ve Seferoğlu, 2017; Kayabaş1, 2008; Seferoğlu, Yıldız ve Avcı Yücel, 2014; Yoğun Erçen, 2009) ve öğretmenlerin mesleki doyumları ile tükenmişlik düzeyleri birlikte araştırılmıştır (Akkurt, 2008; Ertürk ve Keçecioğlu, 2012; İnce ve Şahin, 2016; Sari, 2004). Ayrıca, okul öncesi öğretmenlerinin mesleki sosyal destek düzeylerinin öğretmenlerin tükenmişliklerini yordama düzeyleri (Törnük, 2019), okul öncesi öğretmenlerinin tükenmişlik düzeyleri ile psikolojik destek arayışları arasındaki ilişki (Demirdöğen, 2013) ve eğitimcilerin öz-yeterlik algıları ve tükenmişlik düzeyleri arasındaki ilişkinin belirlenmesi (Karahan ve Uyanık Balat, 2011) amacıyla çeşitli çalışmalar yapılmıştır. Alanyazında, öğretmenlerin örgütsel sinizm düzeylerini inceleyen çalışmalar da bulunmaktadır. Örneğin, öğretmenlerin örgütsel sinizm algıları belirlenmeye çalışılmış (Ada ve Yarım, 2017), örgütsel sinizm düzeyleri çeşitli değişkenler açısından incelenmiş (Kalağan ve Güzeller, 2010), öğretmenlerin örgütsel sinizm düzeylerinin örgütsel bağl1lık düzeyleri (Kılıç, 2011), okul müdürlerinin iletişim becerileri (Özkadam, 2018) ve öğretmenlerin informal iletişim düzeyleri (Arslan, 2018) gibi değişkenlerle ilişkileri araştırılmıştır. Alanyazında çeşitli çalışmalar ise, mesleki tükenmişlik ile örgütsel sinizm arasındaki ilişkiye odaklanmıştır. Örneğin, Mahmood ve Sak (2019) okul öncesi öğretmenlerinin, Karakaya (2019) beden eğitimi öğretmenlerinin, Amasralı ve Aslan (2017) ortaokul ve lise matematik öğretmenlerinin ve Gün ve Atanur Baskan (2017) öğretim elemanlarının mesleki tükenmişlik-örgütsel sinizm ilişkisini belirlemeyi amaçlamışlardır.

Yapılan alanyazın taraması, öğretmenlerin mesleki tükenmişlik düzeyleri ile örgütsel sinizm düzeyleri arasındaki ilişkiyi inceleyen sınırlı sayıda çalışmanın olduğunu, ancak bu 
çalışmaların farklı branşları kapsamaktan ziyade belli bir branştan öğretmenlere odaklandığını göstermektedir. Ancak Ercan ve Kazançoğlu'nun (2019), özellikle örgütsel etkenlerin de tetiklemesiyle artacak mesleki tükenmişliğin, kişinin algıladığı örgütsel sinizm düzeyini de artıracağına ilişkin yaptıkları vurgu, farklı alanlardan öğretmenlerin mesleki tükenmişlik düzeyleri ile örgütsel sinizm düzeyleri arasındaki ilişkiyi ortaya koymanın önemini göstermektedir. Bununla birlikte, böyle bir çalışma hem alanyazındaki bir boşluğu dolduracak hem de öğretmenlik mesleğine ilişkin yapılacak iyileştirme çalışmalarında önemli bir başlangıç noktası olabilecektir. $\mathrm{Bu}$ nedenle bu çalışmanın amacı, farklı branşlardan öğretmenlerin mesleki tükenmişlik düzeyleri ile örgütsel sinizm tutumlarının incelenmesidir. $\mathrm{Bu}$ amaç doğrultusunda aşağıdaki problem cümlesine cevap aranmıştır?

Farklı branşlardan öğretmenlerin mesleki tükenmişlik düzeyleri ile örgütsel sinizm tutumları ne düzeydedir?

Araştırmada ayrıca aşağıda verilen alt sorulara yanıt bulmaya çalışılmıştır:

1. Öğretmenlerin mesleki tükenmişlik düzeyleri çeşitli değişkenlere (branş, cinsiyet, yaş, kıdem, öğrenim düzeyi, okuldaki çalışma durumu [kadrolu-ücretli], çalıştıkları eğitim kademesi, çalıştıkları sektör [özel-devlet], sınıf mevcudu ve son bir yılda meslekleriyle ilgili herhangi bir eğitime/etkinliğe katılma durumu) göre farklılaşmakta midir?

2. Öğretmenlerin örgütsel sinizm tutumları çeşitli değişkenlere (branş, cinsiyet, yaş, kıdem, öğrenim düzeyi, okuldaki çalışma durumu [kadrolu-ücretli], çalıştıkları eğitim kademesi, çalıştıkları sektör [özel-devlet], sınıf mevcudu ve son bir yılda meslekleriyle ilgili herhangi bir eğitime/etkinliğe katılma durumu) göre farklılaşmakta midir?

3. Öğretmenlerin mesleki tükenmişlik düzeyleri ile örgütsel sinizm tutumları arasında anlamlı bir ilişki var mıdır?

\section{Yöntem}

\section{Araştırmanın Deseni}

$\mathrm{Bu}$ çalışmada, farklı branşlardan öğretmenlerin mesleki tükenmişlik düzeyleri ile örgütsel sinizm tutumlarının incelenmesi amaçlandığından tarama modeli kullanılmıştır. Tarama modeli, bir durumu var olduğu şekliyle betimlemeyi amaçlayan araştırma yaklaşımı olarak açıklanmaktadır (Karasar, 2005). Bu çalışmada farklı branşlardan öğretmenlerin mesleki tükenmişlik düzeyleri ile örgütsel sinizm tutumlarının, öğretmenlerin mevcut 
durumlarında herhangi bir değişikliğe ve müdahaleye yer verilmeden olduğu şekliyle incelenmesi amaçlandığından, bu çalışma tarama modelinde dizayn edilmiş bir çalışmadır.

\section{Evren ve Örneklem}

$\mathrm{Bu}$ çalışmanın evrenini, Van ili merkez ilçelerinde resmi ve özel okullarda farklı kademelerde görev yapan öğretmenlerin tamamı oluşturmaktadır. Bu araştırmada örneklem, basit seçkisiz örnekleme yöntemi ile belirlenmiştir. Seçkisiz örnekleme yöntemlerinin temel özelliği, örnekleme birimlerinin örnekleme seçilme olasılıklarının eşit ve bağımsız olmasından dolayı örneklemin evreni temsil etme gücünün yüksek olmasıdır (Büyüköztürk, Kılıç, Çakmak, Akgün, Karadeniz ve Demirel, 2014). Bu araştırmanın örneklemini, Van ili merkez ilçelerinde resmi ve özel okullarda farklı kademelerde görev yapan öğretmenlerden seçkisiz örnekleme yöntemiyle belirlenen 313 öğretmen oluşturmuştur.

Tablo 1. Örnekleme Ait Demografik Bilgiler

\begin{tabular}{|c|c|c|c|}
\hline Değişkenler & & $\mathbf{n}$ & $\%$ \\
\hline \multirow{5}{*}{ Branş } & Okul öncesi & 77 & 24,6 \\
\hline & Türkçe & 67 & 21,4 \\
\hline & Coğrafya & 63 & 20,1 \\
\hline & Matematik & 53 & 16,9 \\
\hline & Sinif & 53 & 16,9 \\
\hline \multirow{2}{*}{ Cinsiyet } & Kadın & 206 & 65,8 \\
\hline & Erkek & 107 & 34,2 \\
\hline \multirow{4}{*}{ Yaş } & 24 ve aşağısı & 22 & 7,0 \\
\hline & $25-29$ & 56 & 17,9 \\
\hline & $30-34$ & 60 & 19,2 \\
\hline & 35 ve yukarısı & 175 & 55,9 \\
\hline \multirow{3}{*}{ Mesleki Kıdem } & 4 y1l ve aşağ 1 s1 & 77 & 24,6 \\
\hline & $5-9$ yil & 71 & 22,7 \\
\hline & 10 yıl ve üzeri & 165 & 52,7 \\
\hline \multirow{2}{*}{ Öğrenim Düzeyi } & Lisans & 267 & 85,3 \\
\hline & Yüksek lisans & 46 & 14,7 \\
\hline \multirow{2}{*}{ Çalışma Durumu } & Kadrolu & 271 & 86,6 \\
\hline & Ücretli & 42 & 13,4 \\
\hline \multirow{4}{*}{ Eğitim Kademesi } & Okulöncesi & 77 & 24,6 \\
\hline & İlkokul & 53 & 16,9 \\
\hline & Ortaokul & 88 & 28,1 \\
\hline & Lise & 95 & 30,4 \\
\hline \multirow{2}{*}{ Çalışılan Sektör } & Özel sektör & 40 & 12,8 \\
\hline & Devlet & 273 & 87,2 \\
\hline \multirow{5}{*}{ Sınıftaki çocuk sayısı } & $16-20$ & 81 & 25,9 \\
\hline & $21-25$ & 52 & 16,6 \\
\hline & $26-30$ & 65 & 20,8 \\
\hline & $31-35$ & 78 & 24,9 \\
\hline & $36-40$ & 37 & 11,8 \\
\hline \multirow{2}{*}{ Seminer/Eğitim alma durumu } & Evet & 133 & 42,5 \\
\hline & Hayır & 180 & 57,5 \\
\hline
\end{tabular}


Tablo 1'e göre, araştırmaya katılan öğretmenlerin 77'si okul öncesi öğretmenliği, 67'si Türkçe, 63'ü coğrafya, 53'ü matematik ve 53'ü sınıf öğretmenliği branşlarında çalışmaktadırlar. Öğretmenlerin 206'sı kadın, 107'si erkektir. Yaşlarının dağılımına bakıldığında, 22 öğretmenin 24 ve altı, 56 öğretmenin 25-29, 69 öğretmenin 30-34 ve 175 öğretmenin 35 ve üstü yaş aralığında oldukları görülmektedir. Öğretmenlerin yarısından fazlası (n=165) 10 yıl ve üzeri kıdeme sahiptir ve \%85,3'ü lisans mezunudur. Tablo 1 ayrıca, 271 öğretmenin kadrolu olarak çalıştığını, 273 öğretmenin ise devlet okullarında görev yaptığını göstermektedir. Öğretmenlerin $\% 57,5$ 'i son bir yılda meslekleriyle ilgili bir eğitime katılmamıştır

\section{Veri Toplama Araçları}

$\mathrm{Bu}$ araştırmada veri toplama aracı olarak Kişisel Bilgi Formu, Maslach Tükenmişlik Envanteri-Eğitimci Formu (İnce ve Şahin, 2015) ve Örgütsel Sinizm Ölçeği (Sağır ve Oğuz, 2012) kullanılmıştır?

Kişisel Bilgi Formu. Araştırmada kullanılan kişisel bilgi formu araştırmacılar tarafından hazırlanmıştır. Kişisel bilgi formunda, branş, cinsiyet, yaş, mesleki kıdem, öğrenim düzeyi, çalışma durumu (kadrolu-ücretli), çalışılan eğitim kademesi, çalışılan sektör (özeldevlet), sınıf mevcudu ve öğretmenlerin son bir yılda mesleklerine yönelik eğitim alıp almama durumlarına yönelik sorular bulunmaktadır.

Maslach Tükenmişlik Envanteri-Eğitimci Formu. İnce ve Şahin (2015) tarafindan Türkçeye uyarlanan ölçeğin orijinali Maslach, Jackson ve Schwab tarafından geliştirilmiş olup, ölçek 7'li likert tipinde 22 maddeden oluşmaktadır. Ölçek, duygusal tükenme boyutunda 9 madde, duyarsızlaşma boyutunda 5 madde ve kişisel başarı boyutunda 8 madde olmak üzere üç alt boyuttan oluşmaktadır. Maslach Tükenmişlik Envanteri-Eğitimci Formundaki alt boyutlar ayrı ayrı puanlanmaktadır. Ölçeğin duygusal tükenme alt boyutunda en yüksek 54, duyarsızlaşma boyutunda 30 ve kişisel başarı boyutunda ise 48 puan alınabilir. Ancak, kişisel başarı alt boyutu diğer iki alt boyuttan farklı yorumlanmaktadır. Diğer bir ifadeyle, kişisel başarı alt boyutunda alınan yüksek puanların karşılığı düşük düzeyde yaşanan tükenmişliktir. Cronbach Alfa iç tutarlılık güvenirlik katsayısı duygusal tükenme boyutu için .88, duyarsızlaşma boyutu için .78 ve kişisel başarı boyutu için .74'tür (İnce ve Şahin, 2015).

Örgütsel Sinizm Ölçeği (ÖSÖ). Öğretmenler için hazırlanan Örgütsel Sinizm Ölçeği, Sağır ve Oğuz (2012) tarafından geliştirilmiştir. Ölçek, çalıştı̆̆ı kurumdan (duyuşsal ve davranışsal) uzaklaşma, performansı düşüren etkenler, okula karşı olumsuz tutum ve çalışanların kararlara/uygulamalara katılımı olmak üzere dört alt boyut ve toplamda 25 
maddeden oluşmaktadır. Çalıştığı kurumdan (duyuşsal ve davranışsal) uzaklaşma alt boyutu yedi, performansı düşüren etkenler alt boyutu dokuz, okula karşı olumsuz tutum alt boyutu beş ve çalışanların kararlara/uygulamalara katılımı alt boyutu dört maddeden oluşmaktadır. Çalışanların kararlara/uygulamalara katılımı alt boyutundaki maddeler ters puanlanan maddelerdir. Bu dört alt boyut, toplam varyansın \%59'unu açıklamaktadır. Cronbach Alfa iç tutarlılık güvenirlik katsayısı birinci faktör için .86, ikinci faktör için .88 , üçüncü faktör için .85, dördüncü faktör için .68 ve ölçeğin genel toplamı için .89 olarak hesaplanmıştır. Örgütsel Sinizm Ölçeğinden alınabilecek en düşük puan 25 iken en yüksek puan ise 125 'tir. Ölçekten alınacak yüksek puanlar öğretmenlerin çalıştıkları kuruma ilişkin olumsuz tutumlarının yüksek olduğunu göstermektedir (Sağır ve Oğuz, 2012).

\section{Verilerin Analizi}

Veri analizine başlamadan önce, veri toplama araçlarının uygun doldurulup doldurulmadıkları (cevapsız-boş bırakılan madde sayısı ya da aynı maddeye birden fazla seçeneğin işaretlenmesi) incelenmiştir. Uygun doldurulmayan 13 ölçek değerlendirmeye alınmamıştır. Toplanan veriler SPSS 22 istatistik paket programı kullanılarak analiz edilmiştir. Çalışmaya katılan öğretmenlerin kişisel bilgi formundaki bilgileri için betimsel analizler yapılarak frekans ve yüzdelikleri hesaplanmıştır. Veri analizinde parametrik ya da non-parametrik testlerden hangilerinin kullanılacağına karar vermek için verilerin normal dağılım gösterip göstermediğini belirlemek amacıyla Kolmogorow-Smirnow testi kullanılmıştır. Kolmogorow-Smirnow testi sonucunda veriler normal dağılım gösterdiğinden $(n=313, p>.05)$ parametrik testlerle analiz yapılmasına karar verilmiştir. Diğer bir ifadeyle, ikiden fazla gruptan oluşan değişkenleri karşılaştırmak için Tek Yönlü Varyans Analizi (ANOVA), iki gruptan oluşan değişkenleri karşılaştırmak için bağımsız örneklemler için ttesti ve mesleki tükenmişliğin alt boyutları ile örgütsel sinizm arasındaki ilişkiyi belirlemek için Pearson Korelasyon Analizi kullanılmıştır.

\section{Bulgular}

Öğretmenlerin mesleki tükenmişlik düzeyleri ile örgütsel sinizm tutumları ne düzeydedir?

Tablo 2. Öğretmenlerin Mesleki Tükenmişlik Düzeyleri

\begin{tabular}{lccccc}
\hline & $\mathbf{N}$ & $\mathbf{M i n .}$ & Maks. & $\overline{\mathbf{X}}$ & S.s \\
\hline Duygusal Tükenme & 313 &, 00 & 54,00 & 16,94 & 11,48 \\
\hline Duyarsılaşma & 313 &, 00 & 21,00 & 4,25 & 5,13 \\
\hline Kişisel Başarı & 313 & 9,00 & 48,00 & 36,91 & 8,21 \\
\hline Örgütsel Sinizm & 313 & 25,00 & 105,00 & 60,79 & 18,65 \\
\hline
\end{tabular}


Mesleki tükenmişliğin duygusal tükenme $(\bar{X}=16,94)$, duyarsızlaşma $(\bar{X}=4,25)$ ve kişisel başarı $(\overline{\mathrm{X}}=36,91)$ boyutlarındaki ortalamaları değerlendirildiğinde katılımcıların mesleki tükenmişlik ortalamalarının düşük olduğu söylenebilir. Öğretmenlerin örgütsel sinizm tutum ortalamalarının $(\overline{\mathrm{X}}=60,79)$ ise orta düzeyde olduğu söylenebilir.

\section{Öğretmenlerin mesleki tükenmişlik düzeyleri branşlarına göre farklılaşmakta mıdır?}

Tablo 3. Öğretmenlerin Mesleki Tükenmişlik Puanlarının Branşlarına Göre Tek Faktörlü ANOVA Sonuçları

\begin{tabular}{|c|c|c|c|c|c|c|c|c|}
\hline & Branş & $\mathbf{N}$ & $\overline{\mathbf{x}}$ & S.s. & Sd & $\mathbf{F}$ & $\mathbf{P}$ & $\begin{array}{c}\text { Anlamlı } \\
\text { Fark }\end{array}$ \\
\hline \multirow{5}{*}{ Duygusal Tükenme } & Okul öncesi & 77 & 13,97 & 9,40 & \multirow{5}{*}{$4 / 308$} & \multirow{5}{*}{3,758} & \multirow{5}{*}{,005 } & \multirow{5}{*}{$\begin{array}{l}\text { C-A } \\
\text { B-A }\end{array}$} \\
\hline & Türkçe & 67 & 19,23 & 12,19 & & & & \\
\hline & Coğrafya & 63 & 20,03 & 11,91 & & & & \\
\hline & Matematik & 53 & 14,64 & 12,07 & & & & \\
\hline & Sinif & 53 & 17,00 & 11,00 & & & & \\
\hline \multirow{5}{*}{ Duyarsızlaşma } & Okul öncesi & 77 & 4,32 & 5,40 & \multirow{5}{*}{$4 / 308$} & \multirow{5}{*}{2,131} & \multirow{5}{*}{,077 } & \multirow{5}{*}{--- } \\
\hline & Türkçe & 67 & 4,35 & 5,09 & & & & \\
\hline & Coğrafya & 63 & 5,50 & 5,45 & & & & \\
\hline & Matematik & 53 & 2,75 & 3,69 & & & & \\
\hline & Sinif & 53 & 4,03 & 5,42 & & & & \\
\hline \multirow{5}{*}{ Kişisel Başarı } & Okul öncesi & 77 & 37,55 & 8,75 & \multirow{5}{*}{$4 / 308$} & \multirow{5}{*}{1,186} & \multirow{5}{*}{,317 } & \multirow{5}{*}{--- } \\
\hline & Türkçe & 67 & 35,44 & 7,78 & & & & \\
\hline & Coğrafya & 63 & 36,28 & 7,96 & & & & \\
\hline & Matematik & 53 & 38,39 & 8,09 & & & & \\
\hline & Sinif & 53 & 37,11 & 8,29 & & & & \\
\hline
\end{tabular}

A:Okul öncesi, B:Türkçe, C:Coğrafya, D:Matematik, E:Sınıf

Öğretmenlerin duygusal tükenmişlik düzeyleri branşlarına göre anlamlı bir farklılık göstermiştir $\left(\mathrm{F}_{308}=3,758, \mathrm{p}<.05\right)$. Farkın hangi gruplar arasında olduğunu belirlemek için yapılan çoklu karşılaştırma testlerinden Tukey testi sonucu incelendiğinde, coğrafya öğretmenleri ile okul öncesi öğretmenleri arasında ve Türkçe öğretmenleriyle okul öncesi öğretmenleri arasında anlamlı bir farklılık olduğu bulunmuştur. Hem coğrafya $(\bar{X}=20,03)$ hem de Türkçe öğretmenlerinin $(\bar{X}=19,23)$ duygusal tükenmişlik düzeylerinin okul öncesi öğretmenlerinin ( $\overline{\mathrm{X}}=13,97)$ duygusal tükenmişlik düzeylerinden daha yüksek olduğu belirlenmiştir. Bunun yanı sıra, öğretmenlerin duyarsızlaşma $\left(F_{308}=2,131, p>.05\right)$ ve kişisel başarı $\left(\mathrm{F}_{308}=1,186, \mathrm{p}>\right.$.05) alt boyutlarına ilişkin tükenmişlik düzeyleri branşlarına göre anlamlı bir farklılık göstermemiştir.

\section{Öğretmenlerin mesleki tükenmişlik düzeyleri cinsiyetlerine göre farklılaşmakta mıdır?}

Yapılan bağımsız örneklemler için t-testi sonucunda, duygusal tükenme $\left(\mathrm{t}_{311}=, 985\right.$, $\mathrm{p}>.05)$, duyarsızlaşma $\left(\mathrm{t}_{311}=, 241, \mathrm{p}>.05\right)$ ve kişisel başarı boyutlarında $\left(\mathrm{t}_{311}=, 967, \mathrm{p}>.05\right)$ aradaki farkın anlamlı olmadığı bulunmuştur. 


\section{Öğretmenlerin mesleki tükenmişlik düzeyleri yaşlarına göre farklılaşmakta mıdır?}

Yapılan Tek Faktörlü ANOVA sonucunda, duygusal tükenme ( $\left.\mathrm{F}_{309}=, 789, \mathrm{p}>.05\right)$, duyarsızlaşma $\left(\mathrm{F}_{309}=, 597, \mathrm{p}>.05\right)$ ve kişisel başarı boyutlarında $\left(\mathrm{F}_{309}=, 388, \mathrm{p}>.05\right)$ anlamlı bir farkl1lık bulunmamıştır.

\section{Öğretmenlerin mesleki tükenmişlik düzeyleri kıdemlerine göre farklılașmakta mıdır?}

Yapılan Tek Faktörlü ANOVA sonucunda, duygusal tükenme $\left(\mathrm{F}_{310}=, 186, \mathrm{p}>.05\right)$, duyarsızlaşma $\left(\mathrm{F}_{310}=1,028, \mathrm{p}>.05\right)$ ve kişisel başarı boyutlarında $\left(\mathrm{F}_{310}=, 729, \mathrm{p}>.05\right)$ anlamlı bir farklılık bulunmamıştır.

\section{Öğretmenlerin mesleki tükenmişlik düzeyleri öğrenim düzeylerine göre farklılaşmakta} midır?

Yapılan bağımsız örneklemler için t-testi sonucunda, duygusal tükenme $\left(\mathrm{t}_{311}=-, 841\right.$, $\mathrm{p}>.05)$, duyarsızlaşma $\left(\mathrm{t}_{311}=-, 163, \mathrm{p}>.05\right)$ ve kişisel başarı boyutlarında $\left(\mathrm{t}_{311}=, 839, \mathrm{p}>.05\right)$ aradaki farkın anlamlı olmadığı bulunmuştur.

Öğretmenlerin mesleki tükenmişlik düzeyleri okuldaki çalışma durumlarına göre farklılaşmakta mıdır?

Tablo 4. Öğretmenlerin Mesleki Tükenmişlik Ölçeği Puanlarının Çalışma Durumlarına Göre t-Testi Sonuçları

\begin{tabular}{lcccccc}
\hline & Çalışma Durumu & $\mathbf{N}$ & $\overline{\mathbf{X}}$ & $\mathbf{S . s}$ & $\mathbf{t}$ & $\mathbf{p}$ \\
\hline \multirow{2}{*}{ Duygusal Tükenme } & Kadrolu & 271 & 17,49 & 11,67 & \multirow{2}{*}{2,175} & \multirow{2}{*}{, 030} \\
\hline \multirow{2}{*}{ Duyarsızlaşma } & Ücretli & 42 & 13,38 & 9,47 & & \multirow{2}{*}{, 306} \\
\hline \multirow{2}{*}{ Kişisel Başarı } & Kadrolu & 271 & 4,37 & 5,15 & \multirow{2}{*}{1,024} & \multirow{2}{*}{, 155} \\
& Ücretli & 42 & 3,50 & 5,01 & & \multirow{2}{*}{1,425} \\
\hline
\end{tabular}

Tablo 4 incelendiğinde, öğretmenlerin çalışma durumlarına (kadrolu-ücretli) göre duygusal tükenme boyutunda $\left(\mathrm{t}_{311}=3,512, \mathrm{p}<.05\right)$ anlamlı bir farklılık bulunmuştur. Analizlere göre, kadrolu çalışan öğretmenlerin duygusal tükenme ortalamaları ( $\overline{\mathrm{X}}=17,49)$, ücretli olarak çalışan öğretmenlerin duygusal tükenme ortalamalarından $(\overline{\mathrm{X}}=13,38)$ daha yüksektir. Diğer bir ifadeyle, kadrolu olarak çalışan öğretmenlerin duygusal tükenmişlikleri ücretli olarak çalışan öğretmenlerinkinden daha yüksek bulunmuştur. Bunun yanı sıra t-testi sonucunda, öğretmenlerin duyarsızlaşma $\left(\mathrm{t}_{311}=1,024, \mathrm{p}>.05\right)$ ve kişisel başarı alt boyutlarında $\left(\mathrm{t}_{311}=-\right.$ $1,425, \mathrm{p}>.05$ ) çalışma durumlarına (kadrolu-ücretli) göre mesleki tükenmişlikleri arasında anlamlı bir farklılık bulunmamıştır. 
Öğretmenlerin mesleki tükenmişlik düzeyleri çalıştıkları eğitim kademesine göre farklılaşmakta mıdır?

Tablo 5. Öğretmenlerin Mesleki Tükenmişlik Puanlarının Çalıştıkları Eğitim Kademesine Göre t-Testi Sonuçları

\begin{tabular}{|c|c|c|c|c|c|c|c|c|}
\hline & Eğitim Kademesi & $\mathbf{N}$ & $\overline{\mathbf{x}}$ & S.s & Sd & $\mathbf{F}$ & $\mathbf{P}$ & $\begin{array}{c}\text { Anlamlı } \\
\text { Fark }\end{array}$ \\
\hline \multirow{4}{*}{ Duygusal Tükenme } & Okulöncesi & 77 & 13,97 & 9,40 & \multirow{4}{*}{ 3/309 } & \multirow{4}{*}{5,785} & \multirow{4}{*}{,001 } & \multirow{4}{*}{$\begin{array}{l}\text { D-A } \\
\text { D-C }\end{array}$} \\
\hline & İlkokul & 53 & 17,00 & 11,00 & & & & \\
\hline & Ortaokul & 88 & 15,48 & 11,20 & & & & \\
\hline & Lise & 95 & 20,67 & 12,62 & & & & \\
\hline \multirow{4}{*}{ Duyarsızlaşma } & Okulöncesi & 77 & 4,32 & 5,40 & \multirow{4}{*}{ 3/309 } & \multirow{4}{*}{1,891} & \multirow{4}{*}{,131 } & \multirow{4}{*}{--- } \\
\hline & İlkokul & 53 & 4,03 & 5,42 & & & & \\
\hline & Ortaokul & 88 & 3,36 & 4,52 & & & & \\
\hline & Lise & 95 & 5,14 & 5,21 & & & & \\
\hline \multirow{4}{*}{ Kişisel Başarı } & Okulöncesi & 77 & 37,55 & 8,75 & \multirow{4}{*}{ 3/309 } & \multirow{4}{*}{1,264} & \multirow{4}{*}{,287 } & \multirow{4}{*}{--- } \\
\hline & İlkokul & 53 & 37,11 & 8,29 & & & & \\
\hline & Ortaokul & 88 & 37,68 & 8,11 & & & & \\
\hline & Lise & 95 & 35,57 & 7,77 & & & & \\
\hline
\end{tabular}

A:Okulöncesi, B: İlkokul, C:Ortaokul, D:Lise

Tablo 5 incelendiğinde, öğretmenlerin çalıştıkları eğitim kademesine göre duygusal tükenme alt boyutunda $\left(\mathrm{F}_{309}=5,785, \mathrm{p}<.05\right)$ anlamlı bir farklılık bulunmuştur. Liselerde çalışan öğretmenlerin duygusal tükenme ortalamalarının $(\bar{X}=20,67)$, hem okul öncesi eğitim kurumlarında çalışanların ortalamalarından $(\overline{\mathrm{X}}=13,97)$ hem de ortaokullarda görev yapan öğretmenlerin ortalamalarından $(\overline{\mathrm{X}}=15,48)$ daha yüksek olduğu belirlenmiştir. Diğer bir ifadeyle, liselerde çalışan öğretmenlerin duygusal tükenmişlikleri okul öncesi eğitim kurumlarında ve ortaokullarda görev yapan öğretmenlerinkinden daha yüksektir. Bunun yanı sıra, tek yönlü ANOVA analizi sonucunda, öğretmenlerin duyarsızlaşma $\left(F_{309}=1,891, p>.05\right)$ ve kişisel başarı alt boyutlarında $\left(\mathrm{F}_{309}=1,264, \mathrm{p}>.05\right)$, çalıştıkları eğitim kademesine göre mesleki tükenmişlikleri arasında anlamlı bir farklılık bulunmamıştır.

\section{Öğretmenlerin mesleki tükenmişlik düzeyleri çalıştıkları sektöre göre farklılaşmakta} midır?

Tablo 6. Öğretmenlerin Mesleki Tükenmişlik Puanlarının Çalıştıkları Sektöre Göre t-Testi Sonuçları

\begin{tabular}{lcccccc}
\hline & Çalışılan Sektör & $\mathbf{N}$ & $\overline{\mathbf{X}}$ & $\mathbf{S . s}$ & $\mathbf{t}$ & $\mathbf{p}$ \\
\hline \multirow{2}{*}{ Duygusal Tükenme } & Özel sektör & 40 & 12,42 & 9,18 & \multirow{2}{*}{$, 2,693$} & \multirow{2}{*}{007} \\
\hline \multirow{2}{*}{ Duyarsızlaşma } & Devlet & 273 & 17,60 & 11,64 & \multirow{2}{*}{, 145} \\
\hline \multirow{2}{*}{ Kişisel Başarı } & Özel sektör & 40 & 3,15 & 4,58 & \multirow{2}{*}{1,460} & \multirow{2}{*}{, 136} \\
& Devlet & 273 & 4,41 & 5,20 & & \multirow{2}{*}{1,493} \\
\hline
\end{tabular}

Tablo 6 incelendiğinde, öğretmenlerin çalıştıkları sektöre göre (özel-devlet) duygusal tükenme boyutunda $\left(\mathrm{t}_{311}=-2,693, \mathrm{p}<.05\right)$ anlamlı bir farkl1lık bulunmuştur. Devlet 
kurumlarında çalışan öğretmenlerin duygusal tükenme ortalamaları $(\overline{\mathrm{X}}=17,60)$, özel sektörde çalışan öğretmenlerin duygusal tükenme ortalamalarından $(\bar{X}=12,42)$ daha yüksektir. Diğer bir ifadeyle, devlete ait okullarda çalışan öğretmenlerin duygusal tükenmişlik düzeylerinin özel okullarda çalışan öğretmenlerinkinden daha yüksek olduğu ortaya çıkmıştır. Bunun yanı sıra t-testi sonucunda, öğretmenlerin duyarsızlaşma $\left(\mathrm{t}_{311}=-1,460, \mathrm{p}>.05\right)$ ve kişisel başarı alt boyutlarında ( $\left.t_{311}=1,493, p>.05\right)$, çalış1lan sektöre (özel-devlet) göre mesleki tükenmişlikleri arasında anlamlı bir farklılık bulunmamıştır.

Öğretmenlerinin mesleki tükenmişlik düzeyleri sınıf mevcuduna göre farklılaşmakta midır?

Yapılan Tek Faktörlü ANOVA sonucunda, duygusal tükenme ( $\left.\mathrm{F}_{308}=, 611, \mathrm{p}>.05\right)$, duyarsızlaşma $\left(\mathrm{F}_{308}=1,192, \mathrm{p}>.05\right)$ ve kişisel başarı alt boyutlarında $\left(\mathrm{F}_{308}=, 380, \mathrm{p}>.05\right)$ aradaki farkın anlamlı olmadığı bulunmuştur.

Öğretmenlerin mesleki tükenmişlik düzeyleri meslekleriyle ilgili herhangi bir eğitime/etkinliğe katılma durumlarına göre farklılaşmakta mıdır?

Yapılan bağımsız örneklemler için t-testi sonucunda, duygusal tükenme ( $\mathrm{t}_{311}=-, 406$, $\mathrm{p}>.05)$, duyarsızlaşma $\left(\mathrm{t}_{311}=-, 600, \mathrm{p}>.05\right)$ ve kişisel başarı boyutlarında $\left(\mathrm{t}_{311}=-, 097, \mathrm{p}>.05\right)$ aradaki farkın anlamlı olmadığı bulunmuştur.

Öğretmenlerin örgütsel sinizm tutumları branşlarına göre farklılaşmakta mıdır?

Tablo 7. Öğretmenlerin Örgütsel Sinizm Puanlarının Branşlarına Göre Tek Faktörlü ANOVA Sonuçları

\begin{tabular}{|c|c|c|c|c|c|c|c|c|}
\hline & Branş & $\mathbf{N}$ & $\overline{\mathbf{x}}$ & S.s. & Sd & $\mathbf{F}$ & $\mathbf{P}$ & $\begin{array}{c}\text { Anlamlı } \\
\text { Fark }\end{array}$ \\
\hline \multirow{5}{*}{ Toplam Sinizm } & Okul öncesi & 77 & 64,62 & 12,84 & \multirow{5}{*}{$4 / 308$} & \multirow{5}{*}{2,748} & \multirow{5}{*}{,028 } & \multirow{5}{*}{ C-D } \\
\hline & Türkçe & 67 & 64,29 & 17,93 & & & & \\
\hline & Coğrafya & 63 & 67,74 & 15,61 & & & & \\
\hline & Matematik & 53 & 58,33 & 15,18 & & & & \\
\hline & Sinıf & 53 & 65,01 & 16,24 & & & & \\
\hline
\end{tabular}

A:Okul öncesi, B:Türkçe, C:Coğrafya, D:Matematik, E:Sınıf

Öğretmenlerin örgütsel sinizm ölçeği puanlarının öğretmenlerin branşlarına göre anlamlı bir farklılık gösterdiği bulunmuştur $\left(\mathrm{F}_{308}=2,748, \mathrm{p}<.05\right)$. Yapılan Tukey testi sonucu incelendiğinde, coğrafya öğretmenlerinin ortalamalarının $(\bar{X}=67,74)$ sınıf öğretmenlerinin ortalamalarından $(\bar{X}=58,33)$ daha yüksek olduğu belirlemiştir. Diğer bir ifadeyle, coğrafya öğretmenlerinin çalıştıkları okullara karşı sınıf öğretmenlerinden daha fazla olumsuz tutuma sahip oldukları söylenebilir. 
Öğretmenlerin örgütsel sinizm tutumları cinsiyetlerine göre farklılaşmakta mıdır?

Tablo 8. Öğretmenlerin Örgütsel Sinizm Puanlarının Cinsiyetlerine Göre t-Testi Sonuçları

\begin{tabular}{ccccccc}
\hline & Cinsiyet & $\mathbf{N}$ & $\overline{\mathbf{X}}$ & S.s & t & p \\
\hline \multirow{2}{*}{ Toplam Sinizm } & Kadın & 206 & 63,41 & 18,31 & \multirow{2}{*}{3,509} & \multirow{2}{*}{001} \\
& Erkek & 107 & 55,74 & 18,36 & & \\
\hline
\end{tabular}

Öğretmenlerin örgütsel sinizm tutumları cinsiyetlerine göre anlamlı bir farklılık ( $\mathrm{t}_{311}=$ 3,509, $\mathrm{p}<.05)$ göstermiştir. Kadınların ortalamalarının $(\overline{\mathrm{X}}=63,41)$ erkelerin ortalamalarından $(\bar{X}=55,74)$ daha yüksek olduğu belirlenmiştir. Diğer bir ifadeyle, kadın öğretmenlerin erkek öğretmenlere göre görev yaptıkları okula ilişkin daha fazla olumsuz tutuma sahip oldukları söylenebilir.

\section{Öğretmenlerin örgütsel sinizm tutumları yaşlarına göre farklılaşmakta mıdır?}

Tablo 9. Öğretmenlerin Örgütsel Sinizm Puanlarının Yaşlarına Göre Tek Yönlü ANOVA Sonuçları

\begin{tabular}{|c|c|c|c|c|c|c|c|c|}
\hline & Yaş & $\mathbf{N}$ & $\overline{\mathbf{x}}$ & S.s. & Sd & $\mathbf{F}$ & $\mathbf{P}$ & $\begin{array}{c}\text { Anlamlı } \\
\text { Fark }\end{array}$ \\
\hline \multirow{4}{*}{ Toplam Sinizm } & 24 ve alt1 & 22 & 71,50 & 15,18 & \multirow{4}{*}{ 3/309 } & \multirow{4}{*}{7,258} & \multirow{4}{*}{,000 } & \multirow{4}{*}{$\begin{array}{l}A-C \\
A-D\end{array}$} \\
\hline & $25-29$ & 56 & 67,76 & 15,49 & & & & \\
\hline & $30-34$ & 60 & 59,83 & 18,51 & & & & \\
\hline & 35 ve üstü & 175 & 57,54 & 19,05 & & & & \\
\hline
\end{tabular}

A:24 ve altı, B:25-29, C:30-34, D:35 ve üstü

Öğretmenlerin örgütsel sinizm tutumları yaşlarına göre anlamlı bir farklılık $\left(\mathrm{F}_{309}=\right.$ 7,258, $\mathrm{p}<.05)$ göstermiştir. Yapılan Tukey testi sonucu incelendiğinde, 24 ve altı $(\overline{\mathrm{X}}=71,50)$ yaş aralığında olan öğretmenlerin örgütsel sinizm tutumlarının, 30-34 ( $\overline{\mathrm{X}}=59,83)$ yaş aralığında olan ve 35 ve üstü $(\overline{\mathrm{X}}=57,54)$ yaş aralığında olan öğretmenlerinin örgütsel sinizm tutumlarından daha yüksek olduğu bulunmuştur.

\section{Öğretmenlerin örgütsel sinizm tutumları kıdemlerine göre farklılaşmakta mıdır?}

Tablo 10. Öğretmenlerin Örgütsel Sinizm Puanlarının Kıdemlerine Göre Tek Yönlü ANOVA Sonuçları

\begin{tabular}{|c|c|c|c|c|c|c|c|c|}
\hline & Kıdem & $\mathbf{N}$ & $\overline{\mathbf{x}}$ & S.s. & Sd & $\mathbf{F}$ & $\mathbf{P}$ & $\begin{array}{c}\text { Anlamlı } \\
\text { Fark }\end{array}$ \\
\hline \multirow{3}{*}{ Toplam Sinizm } & 4 y1l ve altı & 77 & 68,29 & 15,06 & \multirow{3}{*}{$2 / 310$} & \multirow{3}{*}{8,746} & \multirow{3}{*}{,000 } & \multirow{3}{*}{$\begin{array}{l}\text { A-C } \\
\text { A-D }\end{array}$} \\
\hline & $5-9$ y1l & 71 & 59,02 & 18,58 & & & & \\
\hline & 10 yıl ve üzeri & 165 & 58,04 & 19,34 & & & & \\
\hline
\end{tabular}

Öğretmenlerin örgütsel sinizm tutumları kıdemlerine göre anlamlı bir farklılık $\left(\mathrm{F}_{310}=\right.$ 8,746, $\mathrm{p}<.05)$ göstermiştir. Yapılan Tukey testi sonucu incelendiğinde, 4 yıl ve altında $(\bar{X}=68,29)$ kıdeme sahip olan öğretmenlerin örgütsel sinizm tutumlarının, 5-9 yıl ( $\overline{\mathrm{X}}=59,02)$ aralığında kıdemi olan ve 10 yıl ve üzerinde $(\bar{X}=58,04)$ kıdemi olan öğretmenlerinin örgütsel sinizm tutumlarından daha yüksek olduğu bulunmuştur. 
Öğretmenlerin örgütsel sinizm tutumları öğrenim düzeylerine göre farklılaşmakta midır?

Yapılan bağımsız örneklemler için t-testi sonucunda, anlamlı bir farklılık $\left(F_{311}=, 132\right.$, p>.05) bulunmamıştır. Diğer bir ifadeyle, lisans eğitimi ile lisansüstü eğitim almış öğretmenlerin örgütsel sinizm tutumları arasında anlamlı bir farklılık bulunmamıştır.

Öğretmenlerin örgütsel sinizm tutumları okuldaki çalışma durumlarına göre farklılaşmakta mıdır?

Tablo 11. Öğretmenlerin Örgütsel Sinizm Puanlarının Cinsiyetlerine Göre t- Testi Sonuçları

\begin{tabular}{ccccccc}
\hline & Çalsşma & N & $\overline{\mathbf{x}}$ & S.s & t & p \\
\hline \multirow{2}{*}{ Durumu } & Kadrolu & 271 & 59,56 & 19,26 & \multirow{2}{*}{2,995} & \multirow{2}{*}{003} \\
\hline
\end{tabular}

Öğretmenlerin örgütsel sinizm tutumları çalışma durumlarına (kadrolu-ücretli) göre anlamlı bir farkl11ık $\left(\mathrm{t}_{311}=-2,995, \mathrm{p}<.05\right)$ göstermiştir. Ücretli olarak çalışan öğretmenlerin ortalamalarının ( $\overline{\mathrm{X}}=68,71)$ kadrolu olarak çalışan öğretmenlerin ortalamalarından $(\overline{\mathrm{X}}=59,56)$ daha yüksek olduğu belirlenmiştir. Diğer bir ifadeyle, ücretli olarak çalışan öğretmenlerin örgütsel sinizm tutumlarının kadrolu olarak çalışan öğretmenlerin örgütsel sinizm tutumlarından daha yüksek olduğu söylenebilir.

Öğretmenlerin örgütsel sinizm tutumları çalıştıkları eğitim kademesine göre farklılaşmakta mıdır?

Tablo 12. Öğretmenlerin Örgütsel Sinizm Puanlarının Çalıştıkları Eğitim Kademesine Göre Tek Yönlü ANOVA Sonuçları

\begin{tabular}{|c|c|c|c|c|c|c|c|c|}
\hline & Eğitim Kademesi & $\mathbf{N}$ & $\overline{\mathbf{x}}$ & S.s. & Sd & $\mathbf{F}$ & $\mathbf{P}$ & $\begin{array}{c}\text { Anlamlı } \\
\text { Fark }\end{array}$ \\
\hline \multirow{4}{*}{ Toplam Sinizm } & Okulöncesi & 77 & 72,12 & 12,30 & \multirow{4}{*}{ 3/309 } & \multirow{4}{*}{26,420} & \multirow{4}{*}{,000 } & A-B \\
\hline & İlkokul & 53 & 63,73 & 17,48 & & & & A-C \\
\hline & Ortaokul & 88 & 49,20 & 16,37 & & & & A-D \\
\hline & Lise & 95 & 60,69 & 19,48 & & & & B-C \\
\hline
\end{tabular}

A:Okulöncesi, B:İlkokul, C:Ortaokul, D:Lise

Öğretmenlerin örgütsel sinizm tutumları çalıştıkları eğitim kademesine göre anlamlı bir farklılık $\left(\mathrm{F}_{309}=26,420, \mathrm{p}<.05\right)$ göstermiştir. Yapılan Tukey testi sonucu incelendiğinde, okul öncesi eğitim kurumlarında çalışan öğretmenlerin ( $\overline{\mathrm{X}}=72,12)$ örgütsel sinizm tutumlarının, ilkokul ( $\overline{\mathrm{X}}=63,73)$, ortaokul $(\overline{\mathrm{X}}=49,20)$ ve lise $(\overline{\mathrm{X}}=60,69)$ kademelerinde çalışan öğretmenlerin örgütsel sinizm tutumlarından daha yüksek olduğu bulunmuştur. 
Öğretmenlerin örgütsel sinizm tutumları çalıştıkları sektöre göre farklılaşmakta mıdır?

Tablo 13. Öğretmenlerin Örgütsel Sinizm Puanlarının Çalıştıkları Sektöre Göre t-Testi Sonuçları

\begin{tabular}{ccccccc}
\hline & Çalışılan Sektör & $\mathbf{N}$ & $\overline{\mathbf{X}}$ & $\mathbf{S . s}$ & $\mathbf{t}$ & $\mathbf{p}$ \\
\hline \multirow{2}{*}{ Toplam Sinizm } & Özel sektör & 40 & 70,12 & 11,41 & \multirow{2}{*}{3,446} & \multirow{2}{*}{001} \\
& Devlet & 273 & 59,42 & 19,13 & & \\
& &
\end{tabular}

Öğretmenlerin örgütsel sinizm tutumları, çalıştıkları sektöre (özel-devlet) göre anlamlı bir farklılık $\left(\mathrm{t}_{311}=3,446, \quad \mathrm{p}<.05\right)$ göstermiştir. Özel sektörde çalışan öğretmenlerin ortalamalarının $(\overline{\mathrm{X}}=70,12)$ devlet okullarında çalışan öğretmenlerin ortalamalarından $(\overline{\mathrm{X}}=59,42)$ daha yüksek olduğu belirlenmiştir. Diğer bir ifadeyle, özel sektörde çalışan öğretmenlerin örgütsel sinizm tutumlarının devlet okullarında çalışan öğretmenlerin örgütsel sinizm tutumlarından daha yüksek olduğu söylenebilir.

\section{Öğretmenlerinin örgütsel sinizm tutumları sınıf mevcuduna göre farklılaşmakta mıdır?}

Yapılan Tek Yönlü ANOVA sonucunda, anlamlı bir farklılık $\left(\mathrm{F}_{308}=1,502, \mathrm{p}>.05\right)$ bulunmamıştır. Diğer bir ifadeyle, öğretmenlerin örgütsel sinizm tutumları sınıf mevcutlarına göre anlamlı bir farklılık göstermemiştir.

Öğretmenlerin örgütsel sinizm tutumları meslekleriyle ilgili herhangi bir eğitime/etkinliğe katılma durumlarına göre farklılaşmakta mıdır?

Tablo 14. Öğretmenlerin Örgütsel Sinizm Puanlarının Meslekleriyle İlgili Herhangi Bir Eğitime/Etkinliğe Katılma Durumlarına Göre t- Testi Sonuçları

\begin{tabular}{lcccccc}
\hline & $\begin{array}{c}\text { Eğitime/etkinliğe } \\
\text { katılma durumu }\end{array}$ & $\mathbf{N}$ & $\overline{\mathbf{x}}$ & $\mathbf{S . s}$ & $\mathbf{t}$ & $\mathbf{p}$ \\
\hline \multirow{2}{*}{ Toplam Sinizm } & Evet & 133 & 56,66 & 19,05 & $-3,424$ &, 001 \\
\hline
\end{tabular}

Öğretmenlerin örgütsel sinizm tutumları öğretmenlerin meslekleriyle ilgili herhangi bir eğitime/etkinliğe katılma durumlarına göre anlamlı bir farklılık $\left(\mathrm{t}_{311}=-3,424, \mathrm{p}<.05\right)$ göstermiştir. Meslekleriyle ilgili herhangi bir eğitime/etkinliğe katılmamış öğretmenlerin ortalamalarının ( $\overline{\mathrm{X}}=63,84)$ meslekleriyle ilgili herhangi bir eğitime/etkinliğe katılmış öğretmenlerin ortalamalarından $(\bar{x}=56,66)$ daha yüksek olduğu belirlenmiştir. Diğer bir ifadeyle, meslekleriyle ilgili herhangi bir eğitime/etkinliğe katılmamış öğretmenlerin örgütsel sinizm tutumlarının meslekleriyle ilgili herhangi bir eğitime/etkinliğe katılmış öğretmenlerin örgütsel sinizm tutumlarından daha yüksek olduğu söylenebilir. 
Öğretmenlerin mesleki tükenmişlik düzeyleri ile örgütsel sinizm tutumları arasında anlamı bir ilişki var mıdır?

Tablo 15. Öğretmenlerin Mesleki Tükenmişlik Düzeyleri ile Örgütsel Sinizm Tutumları Arasındaki İlișki

\begin{tabular}{lcccc}
\multicolumn{1}{c}{ Değişkenler } & $\mathbf{1}$ & $\mathbf{2}$ & $\mathbf{3}$ & $\mathbf{4}$ \\
\hline 1. Duygusal Tükenme & 1 &, $597^{* *}$ &,$- 423^{* *}$ &, $287^{* *}$ \\
\hline 2. Duyarsızlaşma & & 1 &,$- 483^{* *}$ &, $255^{* *}$ \\
\hline 3. Kişisel Başarı & & & 1 &,$- 215^{* *}$ \\
\hline 4. Sinizm & & & 1 \\
\hline${ }^{*}<.05{ }^{* *} \mathrm{p}<.01$ & & & &
\end{tabular}

Pearson korelasyon analizi yapılarak incelenen öğretmenlerin mesleki tükenmişlik düzeyleri ile örgütsel sinizm tutumları arasındaki ilişki anlamlı farklılıklar göstermiştir. Mesleki tükenmişliğin duygusal tükenme boyutu ile örgütsel sinizm $(\mathrm{r}=, 287, \mathrm{p}<.01)$ arasında pozitif yönde anlamlı bir ilişki bulunmuştur. Diğer bir ifadeyle, öğretmenlerin duygusal tükenmişliklerinin artması durumunda sinizm tutumlarının da artacağı söylenebilir. Mesleki tükenmişliğin duyarsızlaşma boyutu ile sinizm tutumları $(r=, 255, \mathrm{p}<.01)$ arasında pozitif yönde anlamlı bir ilişki bulunmuştur. Diğer bir ifadeyle, öğretmenlerinin mesleki duyarsızlaşmalarının artması durumunda örgütsel sinizm tutumlarının da artacağı söylenebilir. Mesleki tükenmişliğin kişisel başarı boyutu ile sinizm tutumları $(\mathrm{r}=-, 215, \mathrm{p}<.01)$ arasında negatif yönde anlamlı bir ilişki bulunmuştur. Diğer bir ifadeyle, öğretmenlerin kişisel başarılarının artması durumunda örgütsel sinizm tutumlarının azalacağı söylenebilir.

\section{Tartışma}

$\mathrm{Bu}$ çalışmada, farklı branşlardan öğretmenlerin mesleki tükenmişlik düzeyleri ile örgütsel sinizm tutumları incelenmiştir. Örneğin, öğretmenlerin branşlarına göre mesleki tükenmişlikleri incelendiğinde, çalışmaya katılan coğrafya ve Türkçe öğretmenlerinin duygusal tükenmişlik düzeylerinin okul öncesi öğretmenlerinin duygusal tükenmişlik düzeylerinden daha yüksek olduğu bulunmuştur. Bu bulgu, Yalçın (2013) tarafından yapılan çalışmanın, öğretmenlerin branşlarına göre mesleki tükenmişlikleri arasında anlamlı farklılık olduğu bulgusuyla paralellik göstermektedir. Yalçın'ın (2013) çalışmasında branş öğretmenlerinin mesleki tükenmişlikleri sınıf öğretmenlerinkinden daha yüksek çıkmıştır. Türkiye'de özellikle ortaokul ve lise kademelerinde öğrenciler belirli sinavlara hazırlanmaktadırlar. Bu yüzden gerek ebeveynlerin gerekse okul yönetiminin özellikle branş öğretmenlerinden beklentileri artmaktadır. $\mathrm{Bu}$ durumun da öğretmenlerde baskıyı ve buna bağlı olarak da duygusal tükenmişliği artırdığı düşünülmektedir.

Öğretmenlerin mesleki tükenmişlik düzeyleri cinsiyetlerine göre anlamlı farklılık göstermemiştir. $\mathrm{Bu}$ bulgu daha önce yapılmış çalışmaların bulgularıyla paraleldir (Akman, 
Taşkın, Özden ve Çörtü, 2010; Koç, 2015; Mahmood ve Sak, 2019; Yalçın, 2013). Öğretmenlerin mesleki tükenmişlik düzeylerinde cinsiyetleri açısından anlamlı bir farklılığın olmamasının, her iki cinsiyetteki öğretmenlerin aynı koşullarda çalışıyor olmalarından kaynaklandığg düşünülmektedir.

Öğretmenlerin mesleki tükenmişlik düzeyleri yaşlarına göre anlamlı farklılık göstermemiştir. $\mathrm{Bu}$ bulgu, daha önce yapılmış bazı çalışmaların sonuçları ile paralellik gösterirken, bazılarınınkiyle örtüşmemektedir. Diğer bir ifadeyle, yapılmış bazı çalışmalarda yaş değişkeninin öğretmenlerin mesleki tükenmişlikleri üzerinde etkili olduğu (Metin ve Saçan, 2017; Öztürk ve Deniz, 2008), bazılarında ise mesleki tükenmişliğin öğretmenlerin yaşına göre anlamlı bir şekilde farklılaşmadığı belirlenmiştir (Gürbüz, 2008; Mahmood ve Sak, 2019; Yalçın, 2013).

Öğretmenlerin mesleki tükenmişlik düzeyleri kıdemlerine göre anlamlı bir farklılık göstermemiştir. Yaş ve kıdem arasındaki ilişki göz önünde bulundurulduğunda kıdem değişkeninin de anlamlı bir farklılık göstermemesi beklenen bir sonuçtur. Öğretmenlerin mesleki tükenmişliklerine ilişin daha önce yapılmış çalışmalardan bazılarında, farklı branşlardaki öğretmenlerin mesleki tükenmişlik düzeyleri kıdemlerine göre anlamlı bir farkl1lık göstermişken (Cinay, 2015; Çolakoğlu, 2014; Gürbüz, 2008; Koç, 2015; Tunaboylu, 2015; Yalçın, 2013), bazı çalışmalarda bu değişkene göre anlamlı bir farklılık bulunmamıştır (Adiloğulları, 2013; Çintiriz, 2016; Erkul, 2014; Ertürk, 2012; Tunç, 2013). Dolayısıyla çalışmanın bu bulgusu daha önceki bazı çalışmaların bulgularıyla paralellik gösterirken, bazı çalışmalarınkiyle örtüşmemektedir.

Öğretmenlerin mesleki tükenmişlik düzeyleri öğrenim düzeylerine göre anlamlı farkl111k göstermemiştir. Ancak, Mahmood ve Sak (2019) ve Öztürk ve Deniz (2008) tarafından yapılan çalışmalarda farklı sonuçlara ulaşılmıştır. Daha önce yapılan çalışmalarda lisans mezunu ve ön lisans mezunu öğretmenlerin mesleki tükenmişlikleri karşılaştırılmışken, bu çalışmada lisans ve lisansüstü mezunu öğretmenlerin mesleki tükenmişlikleri karşılaştırılmıştır. Çalışmaların bulgularındaki farklılık bundan kaynaklanıyor olabilir.

Öğretmenlerin mesleki tükenmişlik düzeyleri okuldaki çalışma durumlarına (kadroluücretli) göre incelendiğinde, kadrolu olarak çalışan öğretmenlerin duygusal tükenmişlikleri ücretli olarak çalışan öğretmenlerden daha yüksek bulunmuştur. Mahmood ve Sak (2019) da kadrolu olarak çalışan okul öncesi öğretmenlerinin ücretli olarak çalışan okul öncesi öğretmenlerinden daha fazla mesleki tükenmişlik yaşadıklarını belirlemişlerdir. Bu bulgunun ortaya çıkmasında, iş garantilerinin olmasından dolayı kadrolu olarak çalışan öğretmenlerin 
kendilerini mesleki anlamda geliştirmeye kapatmış olmaları ve yaptıkları işte alışkanlıklarının ön plana çıkmış olmasının etkili olduğu düşünülmektedir. Bununla birlikte, kadrolu öğretmenlerin çalıştıkları grupları daha çok sahiplenerek süreçte daha çok yoruluyor olmaları, ücretli öğretmenlerin ise geçici olduklarını düşündükleri için süreçte kendilerini daha rahat hissetmeleri de bu sonucun çıkmasında etkili olabilir. Bir başka ifadeyle, ücretli öğretmenler kadrolu olmadıkları için iyi bir performans sergileme çabası içerisinde olabilir. Bu nedenle, bir sonraki yılda da görevlendirilebilmek için daha fazla ve gözle görünür etkinlikler yapma, eğitim ortamını daha canlı tutma ve kendilerini geliştirme isteği içerisinde olmaları mümkündür. $\mathrm{Bu}$ durumda da kendilerine yatırım yapıyor olmalarından ve bu yatırımın onları tükenmişlik hissetmekten alıkoyuyor olması söz konusu olabilir. Kadrolu öğretmenler ise garantici bakış açısından kaynaklı bir bıkkınlık, bezginlik hissi yaşıyor ya da rehavete daha çabuk kapılıyor olabilirler.

Öğretmenlerin mesleki tükenmişlik düzeyleri çalıştıkları eğitim kademesine göre incelendiğinde, liselerde çalışan öğretmenlerin duygusal tükenmişliklerinin okul öncesi eğitim kurumlarında ve ortaokullarda çalışan öğretmenlerinkinden daha yüksek olduğu bulunmuştur. Bunun yanı sıra, öğretmenlerin duyarsızlaşma ve kişisel başarı alt boyutlarında, çalıştıkları eğitim kademesine göre mesleki tükenmişlikleri arasında anlamlı bir farklılık bulunmamıştır. Lise kademesinde gerek öğretmenler gerekse öğrenci ve aileler üzerinde üniversiteye giriş sınavının yarattı̆ğ yoğun bir stres ve baskı vardır. $\mathrm{Bu}$ nedenle de liselerde görev yapan öğretmenlerin duygusal tükenmişliklerinin daha yüksek çıktığı düşünülmektedir.

Öğretmenlerin mesleki tükenmişlik düzeyleri çalıştıkları sektöre (özel-devlet) göre incelendiğinde, devlet okullarında çalışan öğretmenlerin duygusal tükenmişlik düzeyleri özel okullarda çalışan öğretmenlerden daha yüksek bulunmuştur. Devlet okullarında çalışan öğretmenlerin iş garantilerinin olması, zaman içerisinde meslekleriyle ilgili kendilerini geliştirme motivasyonlarını köreltmiş olabilir. Bunun yanı sıra, devlet okullarında öğretmen öğrencilerle ilgili daha fazla sorumluluk alırken, özel okullarda bu sorumluluk velilerle daha fazla paylaşılabilmektedir. Bu durumların öğretmenlerin duygusal tükenmişliklerini artırmış olabileceği düşünülmektedir.

Öğretmenlerin mesleki tükenmişlik düzeyleri sınıf mevcutlarına göre anlamlı farklılık göstermemiştir. Mahmood ve Sak (2019) benzer sonuçlara ulaşırken, Metin ve Saçan'ın (2017) çalışmasında farklı bir sonuç ortaya çıkmıştır. Ayrıca, her ne kadar bu çalışmada sınıf mevcuduna göre öğretmenlerin mesleki tükenmişlikleri anlamlı bir farklılık göstermemiş olsa 
da kalabalık sınıflardaki öğretmenlerin mesleki tükenmişliklerinin daha yüksek olacağına ilişkin genel bir kanı bulunmaktadır.

Öğretmenlerin örgütsel sinizm ölçeği puanları öğretmenlerin branşlarına göre incelendiğinde, coğrafya öğretmenlerinin çalıştıkları okullara karşı sınıf öğretmenlerinden daha fazla olumsuz tutuma sahip oldukları bulunmuştur. Bu bulgu daha önce Ergen (2015) tarafından yapılan çalışmanın bulgusuyla benzerlik gösterirken Kılıç (2011) tarafından yapılan çalışmayla farklılık göstermektedir. Coğrafya öğretmenlerinin çalıştığı öğrenci grupları birtakım merkezi sınavlara hazırlandıklarından, bu branş öğretmenleri aile ve okul idaresinin baskısını fazlasıyla hissediyor olabilirler. Bu durum da öğretmenlerin sinizm düzeyini artırıyor olabilir.

Kadın öğretmenlerin okullarına ilişkin erkek öğretmenlerden daha fazla olumsuz tutuma sahip oldukları bulunmuştur. Bu bulgu, Mahmood ve Sak (2019) tarafindan yapılan çalışmanın, erkek okul öncesi öğretmenlerinin örgütsel sinizm tutumlarının kadın okul öncesi öğretmenlerinkinden daha yüksek olduğu şeklindeki bulguyla örtüşmemektedir. Ancak bu farklılık, erkeklerin okul öncesi eğitim alanındaki sayılarının ve bu alanın kadın ağırlıklı olmasının bir sonucu olabilir. Diğer branşlarda ise, kadın ve erkek sayıları kısmen daha dengeli dağılmakla birlikte, özellikle ortaokul ve liselerde çalışan kadın öğretmenlerin istenmeyen öğrenci davranışlarıyla ve disiplin sorunlarıyla baş etme konusunda zorlanmalarının onların daha fazla olumsuz tutuma sahip olmaları üzerinde etkili olduğu düşünülmektedir.

24 ve altı yaş aralığında olan öğretmenlerin örgütsel sinizm tutumlarının, 30-34 yaş aralığında olan ve 35 ve üstü yaş aralığında olan öğretmenlerinin örgütsel sinizm tutumlarından daha yüksek olduğu bulunmuştur. $\mathrm{Bu}$ bulgu, daha önce yapılmış bazı çalışmaların bulguları ile paralellik gösterirken (Amasralı, 2016; Karademir, 2016; Kılıç, 2011; Polat, 2014), bazıları ile de örtüşmemektedir (Bölükbaşığlu, 2013; Mahmood ve Sak, 2019; Özcan, 2014; Polatcan, 2012; Uzun, 2015; Yıldırım, 2015; Yüksel, 2015). Bu çalışmada, daha genç öğretmenlerin örgütsel sinizm tutumlarının daha yüksek çıkmasında, yeni mezun öğretmenlerin daha idealist olmalarına rağmen okullarda beklentilerine yanıt bulamamış olmalarının etkili olduğu düşünülmektedir.

4 yıl ve daha az süre kıdemi olan öğretmenlerin örgütsel sinizm tutumlarının, 5-9 yıl aralığında kıdemi olan ve 10 yıl ve daha fazla süre kıdemi olan öğretmenlerin örgütsel sinizm tutumlarından daha yüksek olduğu bulunmuştur. Bu bulgu daha önce yapılmış bazı çalışmalar ile paralellik gösterirken (Altınkurt ve Yılmaz, 2016; Amasralı, 2016; Karademir, 2016; Kılıç, 
2011; Kılıç, 2013; Polat, 2014), bazıları ile de örtüşmemektedir (Mahmood ve Sak, 2019; Polatcan, 2012; Özcan, 2014; Uzun, 2015; Y1ldırım, 2015; Yüksel, 2015). Bu sonuç, genç ve idealist öğretmenlerin eğitim sistemine girdiklerinde aradıklarını bulamamalarıyla ilgili olabileceği gibi, kıdemli öğretmenlerin yıllar geçtikçe okul sistemine entegre olup, birçok olumsuz durumu kabul etmiş olmalarından da kaynaklanıyor olabilir.

Öğretmenlerin örgütsel sinizm tutumları öğrenim düzeylerine göre anlamlı farklılık göstermemiştir. $\mathrm{Bu}$ bulgu, daha önce yapılmış bazı çalışmaların bulguları ile paralellik gösterirken (Bölükbaşığlu, 2013; Kuşçu, 2020; Uzun, 2015; Yıldırım, 2015; Yüksel, 2015), bazılarınınki ile örtüşmemektedir (Mahmood ve Sak, 2019; Polat, 2014). Ayrıca, Ergen (2015) tarafından yapılan çalışmada lisansüstü mezunu öğretmenlerin bilişsel ve davranışsal örgütsel sinizm tutumları, lisans mezunu öğretmenlerin bilişsel ve davranışsal örgütsel sinizm tutumlarından daha yüksek çıkmıştır.

Ücretli olarak çalışan öğretmenlerin örgütsel sinizm tutumlarının kadrolu olarak çalışan öğretmenlerin örgütsel sinizm tutumlarından daha yükssek olduğu bulunmuştur. $\mathrm{Bu}$ bulgu, Mahmood ve Sak (2019) tarafından yapılmış çalışmanın bulgusu ile paralellik göstermektedir. Bunun sebebi, Yayla, Sak, Şahin Sak ve Taşkın (2018) tarafindan yapılan çalışmada da vurgulandığı gibi, ücretli öğretmen olarak çalışmanın bazı dezavantajlarının olması ve buna bağlı olarak da bu şekilde çalışan öğretmenlerin mesleki doyumlarının düşük olması olabilir. Örneğin, ücretli olarak çalışan öğretmenler kadrolu olarak çalışan öğretmenler ile aynı işi yapmalarına rağmen, hem aldıkları ücretler çok daha düşüktür hem de birçok sosyal haktan mahrum durumdadırlar. Ayrıca, okul yönetimi, diğer öğretmenler ve veliler tarafindan da çoğu zaman tam olarak öğretmen olarak kabul edilmemektedirler (Yayla vd., 2018). Bu nedenle de ücretli olarak çalışan öğretmenlerin örgütsel sinizm tutumlarının kadrolu olarak çalışan öğretmenlerden daha olumsuz olması beklenen bir sonuçtur.

Okul öncesi öğretmenlerinin örgütsel sinizm tutumları ilkokul, ortaokul ve lise kademelerinde çalışan öğretmenlerin örgütsel sinizm tutumlarından daha yüksek bulunmuştur. Okul öncesi eğitimin önemi günümüzde her ne kadar anlaşılmaya başlansa da okul öncesi öğretmenleri çoğu zaman öğretmen olmaktan çok bakıcı olarak anılmaktadırlar. Okul öncesi öğretmenlerinin teneffüs saatlerinin olmaması, diğer öğretmenlerle sınırlı oranda etkileşime girmeleri, mesleklerinin diğer öğretmenlerinki kadar profesyonelce algılanmaması gibi sebeplerden dolayı okul öncesi öğretmenlerinin örgütsel sinizm tutumları daha yüksek çıkmış olabilir. Özcan (2014) tarafından yapılan çalışmada ilkokul, ortaokul ve liselerde görev yapan öğretmenlerin örgütsel sinizm tutumları arasında anlamlı bir farklılık bulunmamıştır. Ergen 
(2015) tarafından yapılan çalışmada ise, ilkokullarda çalışan öğretmenlerin bilişsel ve davranışsal örgütsel sinizm tutumları liselerde çalışan öğretmenlerinkinden daha yüksek çıkmıştır.

Özel sektörde çalışan öğretmenlerin örgütsel sinizm tutumlarının devlet okullarında çalışan öğretmenlerinkinden daha yüksek olduğu bulunmuştur. Özel sektörde çalışan öğretmenlerin iş garantilerinin olmaması, fazla çalışma saatleri, düşük ücretler ve sürekli veli ve öğrenci memnuniyetini sağlama gibi etmenlerden dolayı özel sektördeki öğretmenlerin örgütsel sinizm tutumlarının daha yüksek çıktığı düşünülmektedir.

Meslekleriyle ilgili herhangi bir eğitime/etkinliğe katılmamış öğretmenlerin örgütsel sinizm tutumlarının meslekleriyle ilgili herhangi bir eğitime/etkinliğe katılmış öğretmenlerinkinden daha yüksek olduğu bulunmuştur. Meslekleriyle ilgili eğitimlere/etkinliklere katılan öğretmenlerin mesleklerini daha iyi yapmaya çalışmaları ve mesleklerini icra ederken kendilerini geliştirmeye çalışmaları hem mesleki doyumlarını hem de motivasyonlarını artıracağından örgütsel sinizm tutumlarının daha düşük çıkması beklenen bir bulgudur.

Öğretmenlerin mesleki tükenmişlik alt boyutları ile örgütsel sinizm tutumları arasında anlamlı ilişki bulunmuştur. Duygusal tükenme ve duyarsızlaşma boyutlarıyla örgütsel sinizm tutumları arasında pozitif, kişisel başarı ile örgütsel sinizm tutumları arasında ise negatif yönde ilişkiler bulunmuştur. Bu bulgu Mahmood ve Sak (2019) tarafından yapılan çalışmanın bulgularıyla paralellik göstermektedir. Mahmood ve Sak (2019) mesleki tükenmişliğin duygusal tükenme ve duyarsızlaşma boyutları ile örgütsel sinizm arasında pozitif yönde, kişisel başarı boyutu ile de negatif yönde anlamlı bir ilişki bulmuşlardır. Benzer bir bulgu Amasralı (2016) tarafindan da ortaya koyulmuştur. Bu bulgular genel itibariyle beklenen bulgular olup, mesleki tükenmişliğin artması durumunda örgütsel sinizm tutumunun da artması beklenmektedir. Ayrıca, bu bulgu Simbula ve Guglielmi'nin (2010) sinizmin öğretmenlerin mesleki tükenmişliklerinin bir boyutu olarak ele alınabileceğine ilişkin önerileriyle de örtüşmektedir.

\section{Sonuç ve Öneriler}

Sonuç olarak, bu çalışmada öğretmenlerin mesleki tükenmişlik düzeyleri cinsiyetlerine, yaşlarına, kıdemlerine, öğrenim düzeylerine, sınıf mevcuduna, son bir yılda meslekleriyle ilgili herhangi bir eğitime/etkinliğe katılıp katılmama durumlarına göre anlamlı bir farklılık göstermemiştir. Ancak, öğretmenlerin mesleki tükenmişlik düzeylerinin branşlarına, okuldaki 
çalışma durumlarına (kadrolu-ücretli), görev yaptıkları eğitim kademesine ve çalıştıkları sektöre (özel-devlet) göre anlamlı farklılık gösterdiği belirlenmiştir. Öğretmenlerin örgütsel sinizm tutumları ise öğrenim düzeylerine göre anlamlı bir farklılık göstermezken, branşlarına, cinsiyetlerine, yaşlarına, kıdemlerine, çalışma durumlarına (kadrolu-ücretli), çalıştıkları kademeye, sektöre (özel-devlet) ve son bir yılda mesleki bir eğitime/etkinliğe katılıp katılmama durumlarına göre tutumlarında anlamlı farklılıklar bulunmuştur. Ayrıca, öğretmenlerin mesleki tükenmişlik alt boyutları ile örgütsel sinizm tutumları arasında anlamlı ilişkiler bulunmuştur.

$\mathrm{Bu}$ sonuçlar göz önünde bulundurulduğunda, hangi branşlardaki öğretmenlerin mesleki tükenmişliklerinin daha düşük ve yüksek çıktığı belirlenerek, bu durumun ortadan kalkması için eylem planları hazırlanabilir. Tükenmişlikle baş etme yollarına ilişkin eğitimler verilerek, öğretmenler, idareciler ve diğer okul çalışanları bilgilendirilebilir. Okulun, öğrencinin ve velinin profili göz önünde bulundurularak, özellikle öğretmenlerden beklentiler daha gerçekçi hale getirilebilir. Öğretmenlerin göstermiş oldukları her türlü çaba takdir edilebilir. İş dağılımı veya ödüllendirme süreçlerinde adil kararların alınmasıyla olumlu bir kurum kültürünün oluşması desteklenebilir ve buna bağlı olarak da okula ilişkin olumsuz tutumların azalması sağlanabilir.

Bundan sonra yapılacak diğer çalışmalarda, bu çalışmada farklı değişkenler açısından belirlenen mesleki tükenmişlik ve örgütsel sinizm tutumlarının sebepleri nitel çalışmalar ile derinlemesine incelenebilir. Yapılacak başka çalışmaların örneklemleri farklı bölgelerden ve daha farklı öğretmenlik branşlarından seçilerek konu daha derinlemesine incelenebilir.

\section{Makalenin Bilimdeki Konumu}

Temel Eğitim/Okul Öncesi Eğitimi

\section{Makalenin Bilimdeki Özgünlüğü}

Özellikle örgütsel etkenlerin de tetiklemesiyle artacak mesleki tükenmişlik, kişinin algıladığı örgütsel sinizm düzeyini artıracaktır. Bu nedenle, farklı alanlardan öğretmenlerin mesleki tükenmişlik düzeyleri ile örgütsel sinizm düzeyleri arasındaki ilişkiyi ortaya koymak hem literatürdeki bir boşluğu doldurması hem de öğretmenlik mesleğine ilişkin yapılacak iyileştirme çalışmalarında bir başlangıç noktası olması açısından önemlidir. 


\section{Kaynaklar}

Ada, Ş. ve Yarım, M. A. (2017). İlkokullarda görev yapan öğretmenlerin örgütsel sinizm algıları: Erzurum ili örneği. Iğdır Üniversitesi Sosyal Bilimler Enstitüsü Dergisi, 13, 6698.

Adams, S. R. (1970). Analysing the teacher's role. Educational Research, 12(2), 121-127.

Adiloğulları, G. E. (2013). Beden eğitimi öğretmenlerinin duygusal zeka ile mesleki tükenmişlik düzeyleri arasındaki ilişkinin incelenmesi. (Yayımlanmamış yüksek lisans tezi). Kahramanmaraş Sütçü İmam Üniversitesi, Kahramanmaraş.

Akkurt, Z. (2008). Okulöncesi öğretmenlerinin iş doyumu ve tükenmişlik düzeylerinin incelenmesi: Istanbul-Pendik örneği. (Yayımlanmamış yüksek lisans tezi). Selçuk Üniversitesi, Konya.

Akman, B., Taşkın, N., Özden, Z. ve Çörtü, F. (2010). A study on preschool teachers’ burnout. Elementary Education Online, 9(2), 807-815.

Alan, H. ve Fidanboy, C. Ö. (2013). Sinizm, tükenmişlik ve kişilik arasındaki ilişkiler: Bilişim sektörü çalışanları kapsamında bir inceleme. Süleyman Demirel Üniversitesi Sosyal Bilimler Enstitüsü Dergisi, 1 (Büro Yönetimi Özel Sayısı), 165-175.

Altınkurt, Y. ve Yılmaz, K. (2016). Öğretmenlerin mizah tarzları ile örgütsel sinizm düzeyleri arasındaki ilişki. Sakarya Üniversitesi Eğitim Fakültesi Dergisi, 32, 122-143.

Amasralı, A. (2016). Ortaokul ve lise matematik ögrretmenlerinin örgütsel sinizm tutumlarl ile mesleki tükenmişlik düzeyleri arasındaki ilişki (Amasya İli Örneği). (Yayımlanmamış yüksek lisans tezi). Ondokuz Mayıs Üniversitesi, Samsun.

Amasralı, A. ve Aslan, H. (2017). Ortaokul ve lise matematik öğretmenlerinin örgütsel sinizm ile tükenmişlik düzeyleri arasındaki ilişki. Mehmet Akif Ersoy Üniversitesi Ĕ̈itim Fakültesi Dergisi, 43, 64-92.

Arslan, N. (2018). Öğretmenlerin informal iletişim düzeylerinin örgütsel sinizm ile ilişkisi. (Yayımlanmamış yüksek lisans tezi). İstanbul Sabahattin Zaim Üniversitesi, İstanbul.

Bağcı, H. ve Karagül, S. (2013). Türkçe öğretmenlerinin mesleki tükenmişlik düzeyi. Mehmet Akif Ersoy Üniversitesi Sosyal Bilimler Enstitüsü Dergisi, 5(8), 184-193.

Baltaş, A. ve Baltaş, Z. (1993). Stres ve başa çıkma yolları. İstanbul: Remzi Kitabevi

Başol, G. ve Altay, M. (2009). Eğitim yöneticisi ve öğretmenlerin mesleki tükenmişlik düzeylerinin incelenmesi. Kuram ve Uygulamada Eğitim Yönetimi, 15(58), 191-216. 
Bateman, T. S., Sakano, T., \& Fujita, M. (1992). Roger, me, and my attitude: Film propaganda and cynicism toward corporate leadership. Journal of Applied Psychology, 77(5), 768-771.

Bölükbaşığlu, K. (2013). Öğretmenlerin örgütsel adalet algılart ile örgütsel sinizm tutumları arasındaki ilişki. (Yayımlanmamış yüksek lisans tezi). Pamukkale Üniversitesi, Denizli.

Büyüköztürk, Ş., Çakmak, E., Akgün, Ö. E., Karadeniz, Ş. ve Demirel, F. (2014). Bilimsel araştırma yöntemleri. Ankara: Pegem Akademi Yayıncılık.

Cherniss C. (1980). Professional burnout in human service organizations. New York: Praeger.

Cinay, F. (2015). Illkokul ögrretmenlerinin mesleki tükenmişlik düzeyleri ile örgütsel vatandaşlık davranışları arasındaki ilişki. (Yayımlanmamış yükssek lisans tezi). Okan Üniversitesi, İstanbul.

Çintiriz, Ş. (2016). Mesleki ve Teknik Anadolu Liselerinde kültür dersi öğretmenlerinin mesleki tükenmişlik düzeyinin tespiti: Beşiktaş ilçesi örneği. (Yayımlanmamış yüksek lisans tezi). İstanbul Aydın Üniversitesi, İstanbul.

Çolakoğlu, İ. (2014). Ortaokullarda görev yapan müzik ögrretmenlerinin mesleki tükenmişlik düzeylerinin incelenmesi. (Yayımlanmamış yüksek lisans tezi). İstanbul Aydın Üniversitesi, İstanbul.

Dağyar, M. ve Kasalak, G. (2018). Eğitim örgütlerinde yaşanan örgütsel sinizmin öncülleri ve sonuçları üzerine bir meta-analiz çalışması. Hacettepe Üniversitesi Eğitim Fakültesi Dergisi, 33(4), 967-986.

Dean, J. W., Brandes, J. P. \& Dharwadkar, R. (1998). Organizational cynicism. The Academy of Management Review, 23(2), 341-352.

Demirdöğen, N. (2013). Okul öncesi öğretmenlerinin tükenmişlik düzeyleri ile psikolojik yardım arayışları arasındaki ilişkinin incelenmesi. (Yayımlanmamış yüksek lisans tezi). Yeditepe Üniversitesi, İstanbul.

Durak, H. Y. ve Seferoğlu, S. S. (2017). Öğretmenlerde tükenmişlik duygusunun çeşitli değişkenler açısından incelenmesi. Gazi Üniversitesi Gazi Ĕ̆itim Fakültesi Dergisi, 37(2), 759-788.

Ercan, A. \& Kazançoğlu, İ. (2019). Algılanan örgütsel sinizmin mesleki tükenmişlik olgusuyla ilişkisi: Satış personeli üzerine bir araştırma. Organizasyon Ve Yönetim Bilimleri Dergisi, 11(2), 1-19. 
Ercan, L. (2003). Motivasyon. L. Küçükahmet (Ed). Sınıf yönetiminde yeni yaklaşımlar içinde (s.103-118). Ankara: Nobel Yayıncıl1k.

Ergen, S. (2015). Öğretmenlerin örgütsel sinizm düzeyleri ile örgütsel bă̆lllıkları arasındaki ilişki. (Yayımlanmamış yüksek lisans tezi). Gazi Üniversitesi, Ankara.

Ergin, C. (1996). Sağlık personelinin iş anlayışları ve tutumları araştırması. Ankara: Sağlık Projesi Genel Koordinatörlüğü.

Erkul, A. (2014). Meslek lisesi öğretmenlerinin mesleki tükenmişlik düzeyi. (Yayımlanmamış yüksek lisans tezi). Bahçeşehir Üniversitesi, İstanbul.

Ertürk, E. ve Keçecioğlu, T. (2012). Çalışanların iş doyumları ile mesleki tükenmişlik düzeyleri arasındaki ilişkiler: Öğretmenler üzerine örnek bir uygulama. Ege Akademik Baklş, 12(1), 39-52.

Ertürk, M. (2012). Özel ve devlet okullarında çalışan okul öncesi öğretmenlerin demografik değişkenlere băglı olarak mesleki tükenmişlik ve anksiyete düzeylerinin karşılaştırılması. (Yayımlanmamış yüksek lisans tezi). Maltepe Üniversitesi, İstanbul.

Freudenberger, H. J. (1989). Burnout: Past, present, and future concerns. Loss, Grief \& Care, 3(1-2), 1-10.

Gün, F. ve Atanur Baskan, G. (2017). Öğretim elemanlarının algılarına göre örgütsel sinizm ile tükenmişlik düzeyleri arasındaki ilişkinin incelenmesi. Hacettepe Üniversitesi Ĕgitim Fakültesi Dergisi, 32(2), 361-379.

Gürbüz, Z. (2008). Kars ilinde görevli okul öncesi ögrretmenlerinin iş tatmin düzeyleri ve mesleki tükenmişlik düzeylerinin incelenmesi. (Yayımlanmamış yüksek lisans tezi). Marmara Üniversitesi, İstanbul.

Işıkhan, V. (2016). Çalışanlarda tükenmişlik sendromu. Gülhan, M., ve Ü, Yılmaz. (Ed.). Akciğer kanserinde destek tedavisi içinde (s. 366-391). Ankara: TÜSAD Eğitim Kitapları Serisi.

İnce, N. B. ve Şahin, A. E. (2016). Birleştirilmiş ve bağımsız sınıflarda çalışan sınıf öğretmenlerinin mesleki doyum ve tükenmişlik düzeylerinin karşılaştırılması. Hacettepe Üniversitesi Ĕ̈itim Fakültesi Dergisi, 31(2), 391-409.

İnce, N. B. ve Şahin, A. E. (2015). Maslach Tükenmişlik Envanteri-Eğitimci Formunu Türkçeye uyarlama çalışması. Eğitimde ve Psikolojide Ölçme ve Değerlendirme Dergisi, 6(2), 385-399. 
Johnson, J. L. \& O’Leary-Kelly, A. M. (2003). The effects of psychological contract breach and organizational cynicism: Not all social exchange violations are created equal. Journal of Organizational Behavior, 24, 627-647.

Kalağan, G. ve Güzeller, C. O. (2010). Öğretmenlerin örgütsel sinizm düzeylerinin incelenmesi. Pamukkale Üniversitesi Eğitim Fakültesi Dergisi, 27, 83-97.

Karademir, M. (2016). Ortaokul öğretmenlerinin okul yönetiminde kayırmacılık algıları ile örgütsel sinizm arasındaki ilişkinin incelenmesi: Ístanbul ili Pendik ilçesi örneği. (Yayımlanmamış yüksek lisans tezi). İstanbul Aydın Üniversitesi, İstanbul.

Karahan, Ş. ve Uyanık Balat, G. (2011). Özel eğitim okullarında çalışan eğitimcilerin özyeterlik algılarının ve tükenmişlik düzeylerinin incelenmesi. Pamukkale Üniversitesi Ĕ̈itim Fakültesi Dergisi, 29, 1-14.

Karakaya, B. (2019). Resmi ve özel okullarda beden eğitimi öğretmenlerinde örgütsel sinizm ve tükenmişlik düzeyleri. (Yayımlanmamış yüksek lisans tezi). İstanbul Gelişim Üniversitesi, İstanbul.

Karasar, N. (2005). Bilimsel araştırma yöntemi. (14. Baskı). Ankara: Nobel Yayınevi.

Kayabaşı, Y. (2008). Bazı değişkenler açısından öğretmenlerin mesleki tükenmişlik düzeyleri. Sosyal Bilimler Dergisi, 20, 191-212.

Kılıç, M. (2013). İlköğretim okullarında görevli ögrretmenlerin örgütsel sinizm düzeyleri ile iş doyumları arasındaki ilişkinin incelenmesi. (Yayımlanmamış yüksek lisans tezi). Gaziantep Üniversitesi, Gaziantep.

Kilıç, Ş. (2011). Illköğretim okulu ögretmenlerinin örgütsel sinizm ve örgütsel bağlllık düzeyleri arasındaki ilişki (Keçiören ilçesi örneği). (Yayımlanmamış yüksek lisans tezi). Hacettepe Üniversitesi, Ankara.

Koç, M. (2015). İlköğretim öğretmenlerinin tükenmişlik düzeyleri ile sinizm arasındaki ilişki (Ă̆rı ili, Patnos ilçesi örneği). (Yayımlanmamış yüksek lisans tezi). Yeditepe Üniversitesi, İstanbul.

Kuşçu, C. (2020). Öğretmenlerin örgütsel sinizm düzeyleri ile örgütsel vatandaşlık davranışları arasındaki ilişki. (Yayımlanmamış yüksek lisans tezi). Uşak Üniversitesi, Uşak.

Mahmood, S. M. R. ve Sak, R. (2019). Okul öncesi öğretmenlerinin mesleki tükenmişlik düzeyleri ile örgütsel sinizm tutumları arasındaki ilişkinin incelenmesi. Kastamonu Eğitim Dergisi, 27(5), 2243-2259. 
Makovec, D. (2018). The teacher's role and professional development. International Journal of Cognitive Research in Science, Engineering and Education, 6(2), 33-45.

Maslach, C., Schaufeli, W. B. \& Leiter, M. P. (2001). Job burnout. Annual Review of Psychology, 52, 397-422.

Metin, Ş. ve Saçan, S. (2017). An analysis of the effects of pre-school teachers' burnout levels on job satisfaction. International Journal of Family, Child and Education, 11, 44-67.

Özcan (2014). Öğretmenlerin örgütsel adalet algıları ile örgütsel sinizm tutumları arasındaki ilişki. (Yayımlanmamış yüksek lisans tezi). Kocaeli Üniversitesi, Kocaeli.

Özkadam, Z. (2018). Illkokul müdürlerinin iletişim becerileri ile ögretmenlerin örgütsel sinizm tutumları arasındaki ilişkinin incelenmesi. (Yayımlanmamış yüksek lisans tezi). İstanbul Sabahattin Zaim Üniversitesi, İstanbul.

Öztürk, A. ve Deniz, M. E. (2008). Analysis of emotional intelligence job satisfaction and burnout levels of preschool teachers according to some variables. Ilkögrretim Online, 7(3), 578-599.

Polat, E. Ç. (2014). Kurum içi etkin iletişim ortamı ile örgütsel sinizm arasındaki ilişki: Öğretmenlerin görüşleri açısından incelenmesi. (Yayımlanmamış yüksek lisans tezi). Erciyes Üniversitesi, Kayseri.

Polatcan, M. (2012). Okul yöneticilerinin liderlik davranışlart ile ögretmenlerin örgütsel sinizm tutumları arasındaki ilişki (Karabük ili örneği). (Yayımlanmamış yüksek lisans tezi). Sakarya Üniversitesi, Sakarya.

Sağır, T. ve Oğuz, E. (2012). Öğretmenlere yönelik örgütsel sinizm ölçeğinin geliştirilmesi. International Journal of Human Sciences, 9(2), 1094-1106.

Sari, H. (2004). An analysis of burnout and job satisfaction among Turkish special school headteachers and teachers, and the factors effecting their burnout and job satisfaction. Educational Studies, 30(3), 291-306.

Seferoğlu, S. S., Yıldız, H. ve Avcı Yücel, Ü. (2014). Öğretmenlerde tükenmişlik: Tükenmişliğin göstergeleri ve bu göstergelerin çeşitli değişkenler açısından incelenmesi. Eğitim ve Bilim, 174, 348-364.

Simbula, S. \& Guglielmi, D. (2010). Depersonalization or cynicism, efficacy or inefficacy: What are the dimensions of teacher burnout? European Journal of Psychology of Education, 25(3), 301-314. 
Törnük, N. (2019). Okul öncesi öğretmenlerinin tükenmişlik düzeylerinin yordayıcısı olarak mesleki sosyal destek algısı. (Yayımlanmamış yüksek lisans tezi), İstanbul Sabahattin Zaim Üniversitesi, İstanbul.

Tunaboylu, M. (2015). Illkokul ve ortaokul öğretmenlerinin mesleki tükenmişlik düzeyleri (İzmir ili Torbalı ilçesi örneği). (Yayımlanmamış yüksek lisans tezi). Okan Üniversitesi, İzmir.

Tunç, V. (2013). Tarih ögretmenlerinin iş doyum ve mesleki tükenmişlik düzeylerinin bazı değişkenler açısından incelenmesi: Van ili örneği. (Yayımlanmamış yüksek lisans tezi). Yüzüncü Y1l Üniversitesi, Van.

Uzun, T. (2015). Okul müdürlerinin iletişim becerileri ile öğretmenlerin genel ve örgütsel sinizm tutumlarl arasındaki ilişkilerin incelenmesi (Giresun ili örneği). (Yayımlanmamış yüksek lisans tezi). Atatürk Üniversitesi, Erzurum.

Yalçın, S. (2013). Illköğretim okulu öğretmenlerinin mesleki tükenmişlik düzeyleri ile stres, psikolojik dayanıklılık ve akademik iyimserlik arasındaki ilişki. (Yayımlanmamış yüksek lisans tezi). Gazi Üniversitesi, Ankara.

Yayla, A., Sak, R., Şahin Sak, İ. T. ve Taşkın, N. (2018). Comparing the job satisfaction of hourly paid and salaried preschool teachers in Turkey. Education 3-13, 46(7), 814-824.

Yıldırım, G. (2015). Lise ögretmenlerinin örgütsel sinizm tutumları ile örgütsel vatandaşlık davranışları arasındaki ilişsk. (Yayımlanmamış yüksek lisans tezi). Gazi Üniversitesi, Ankara.

Yoğun Erçen, A. E. (2009). Öğretmenlerin mesleki tükenmişlik düzeyleri: Mersin ilinde karşılaştırmalı bir inceleme. Çukurova Üniversitesi Ĕ̈itim Fakültesi Dergisi, 3(36), 1-8.

Yüksel, H. (2015). Örgütsel sinizm ve bă̆lllık arasındaki ilişki: İlk ve ortaokul öğretmenleri üzerinde bir araştırma. (Yayımlanmamış yüksek lisans tezi). Dokuz Eylül Üniversitesi, İzmir. 


\section{Summary}

\section{Introduction}

Burnout does not have a standard definition and it is not easy to explain the term. However, Maslach, Schaufeli and Leiter (2001) states that job burnout consists of three dimensions; exhaustion, cynicism and sense of ineffectiveness, and it can be defined as a long-term response to chronic emotional and interpersonal stress factors at work. Teaching is a profession that job burnout is often experienced because the responsibility of a teacher is big and expectations of people such as principals, parents or students from teachers increase their responsibility. It also increases teachers' stress levels and so levels of their job burnout (Mahmood and Sak, 2019).

It is thought that an individual directs his negative feelings to his colleagues or self through burnout and to organization where he worked or administrators through organizational cynicism, and the relationship between them has been the focus of several studies recently (Alan and Fidanboy, 2013). Johnson and O’Leary-Kelly (2003) -based on several studies such as Andersson, 1996; Bateman, Sakano, and Fujita, 1992; Dean, Brandes and Dharwadkar, 1998-, defined organizational cynicism as the attitude resulting from the perception that the organization lacks integrity due to the violation of basic expectations such as honesty, fairness and righteousness in the organization where an individual works.

In literature, there are several studies related to job burnout levels or organizational cynicism attitudes of teachers. Even, some studies focused on the relationship between them (Amasralı and Aslan, 2017; Gün and Atanur Baskan, 2017; Karakaya, 2019; Mahmood and Sak, 2019). However, the number of them is limited and also, they consisted of teachers from specific departments. Therefore, the aim of this study is to examine job burnout levels and organizational cynicism attitudes of teachers from different departments.

\section{Method}

This survey consisted of 313 teachers selected randomly. Teachers were departments of preschool education ( $n=77)$, Turkish $(n=67)$, geography $(n=63)$, math $(n=53)$ and primary school teaching $(n=53)$. The data was collected through Maslach Burnout InventoryEducators Survey adapted to Turkish by İnce and Şahin (2015), Organizational Cynicism Scala developed by Sağır and Oğuz (2012) and Personal Information Form developed by the 
researchers and analyzed through parametric tests; The Independent Samples t-Test, One-way ANOVA and Pearson Correlation Coefficient.

\section{Findings and Discussion}

Analysis showed that there were no statistically significant differences in job burnout levels of teachers based on their genders, ages, teaching experiences, educational levels, class size and if they attended a training program or activities related to their job last year but a statistically significant difference was found based on their department, how they worked (hourly paid or salaried), the age group they taught and the sector they worked (public or private). There was no statistically significant difference in organizational cynicism attitudes of teachers based on their educational levels but a statistically significant difference was found based on their department, genders, ages, teaching experiences, how they worked (hourly paid or salaried), the age group they taught, the sector they worked (public or private) and if they attended a training program or activities related to their job last year.

There was also a statistically significant relationship between teachers' job burnout levels and organizational cynicism attitudes. The relationship between the dimensions of emotional exhaustion or depersonalization and organizational cynicism attitude was positive and the relationship between the dimension of personal accomplishment and organizational cynicism attitude was negative. It was parallel with the findings of Mahmood and Sak (2019), and Amasral1 (2016). It is expected that while job burnout level stimulates organizational cynicism attitude and negative feelings to the organization. Therefore, these findings were expected. Also, these findings support Simbula and Guglielmi's (2010) suggestions which emphasize that cynicism can be accepted as one dimension of job burnout.

\section{Conclusion and Recommendations}

When the findings of the study are considered, an action plan can be prepared for the teachers whose job burnout is high. Teachers, school principals and other school staff can be informed about dealing with job burnout through some seminars. Expectations from especially teachers can be made more realistic through considering profiles of school, students and parents.

For further studies, reasons of teachers' job burnout and organizational cynicism can be examined in detail through qualitative research. Also, sample from different departments and regions can be selected to make a detailed examination. 